\title{
No.6
}

Special Report
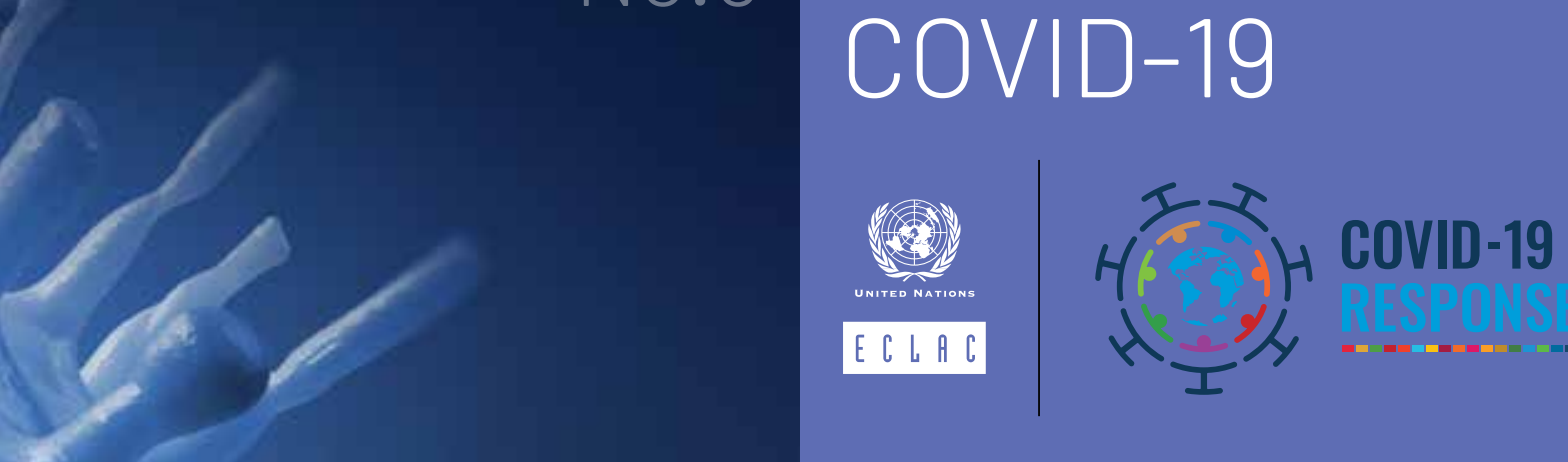

\section{The effects of the coronavirus disease (COVID-19) pandemic on international trade and logistics}

\section{A. Global trade has collapsed ${ }^{1}$}

- The COVID-19 outbreak occurred in a context of sluggish global trade that has been dragging on since the 2008-2009 financial crisis. While the volume of trade in goods grew at an average rate of $6.2 \%$ per year between 1990 and 2007, it expanded by only $2.3 \%$ per year between 2012 and 2019 (see figure 1). Likewise, the share of exports of goods and services in global GDP, which reached a historic high of $31 \%$ in 2008, has been around $28 \%$ since 2015.

Figure 1 | Change in the volume of the global trade in goods, 1990-2019 (Percentages)

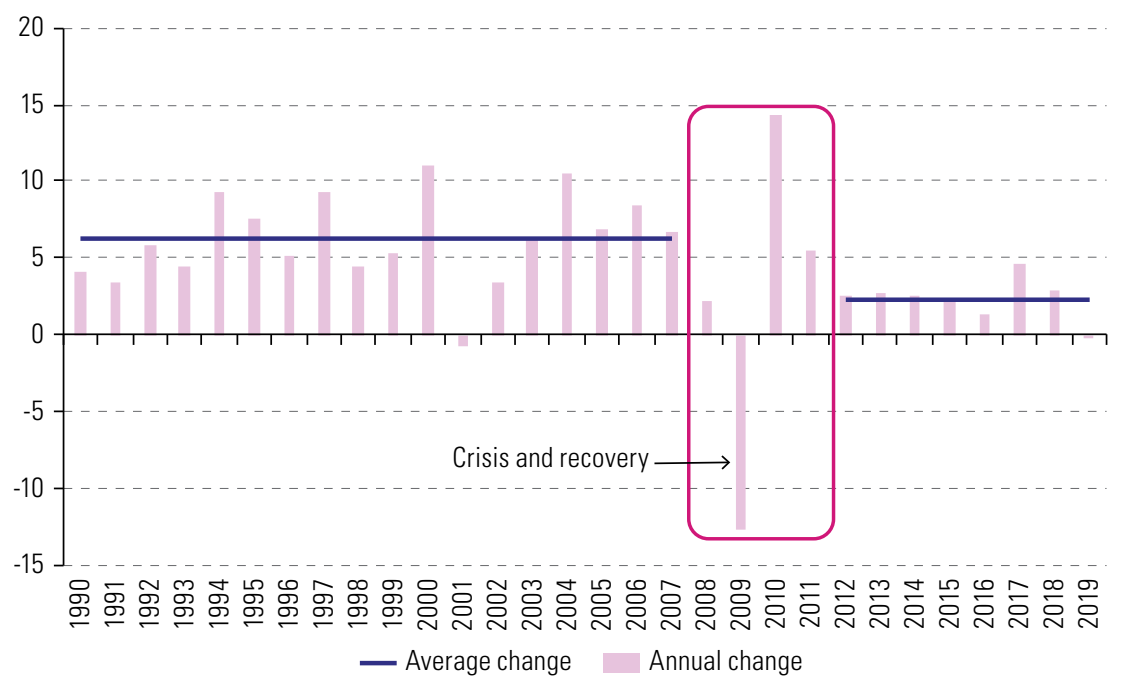

Source: Economic Commission for Latin America and the Caribbean (ECLAC), on the basis of information from the World Trade Organization (WTO).

\section{Contents}

A. Global trade has collapsed .1

B. The region's trade in goods plummeted $17 \%$ between January and May 2020

C. The collapse in tourism is dragging down services exports.

D. International transport problems hamper regional trade.

E. Exports and imports of goods set to decline by a quarter in 2020

F. A more uncertain and regionalized world economy makes further regional integration imperative.

Bibliography 
The rapid spread of COVID-19 and the measures taken by governments to contain it have had serious consequences for the world's major economies. Many productive activities have been disrupted, first in Asia and then in Europe, North America and the rest of the world, and there have been widespread border closures. This has resulted in a steep rise in unemployment, especially in the United States, with a consequent reduction in demand for goods and services. Against this backdrop, global GDP in $\mathbf{2 0 2 0}$ is expected to register its sharpest contraction since the Second World War (World Bank, 2020).

- In this situation, the volume of global trade in goods fell by $17.7 \%$ in May 2020 compared with the same month in 2019 (see figure 2). The drop in the first five months of the year was widespread, although it particularly affected exports from the United States, Japan, and the European Union (see table 1). The economic contraction in China was smaller than the global average, as that country controlled the outbreak and reopened its economy relatively quickly. Latin America and the Caribbean is the most affected developing region.

Figure 2 | Year-on-year change in the volume of global trade in goods, January 2017-May 2020 (Percentages)

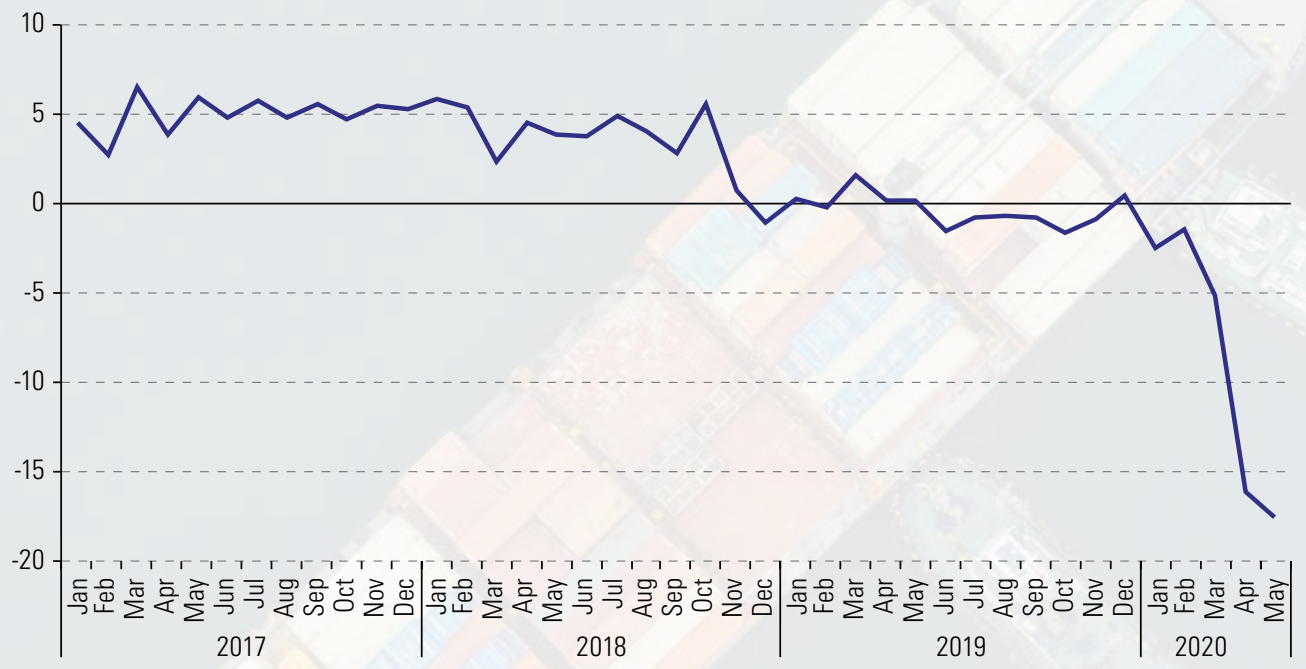

Source: Economic Commission for Latin America and the Caribbean (ECLAC), on the basis of Netherlands Bureau of Economic Policy Analysis (CPB), World Trade Monitor [online database] https://www.cpb.nl/en/worldtrademonitor.

Table 1 | World and selected groups and countries: change in the volume of global trade in goods, December 2019-May 2020

(Percentages)

\begin{tabular}{lcc}
\hline & Exports & Imports \\
\hline World & -18.3 & -15.8 \\
\hline Advanced economies & -22.7 & -15.8 \\
\hline United States & -30.8 & -15.8 \\
\hline Japan & -22.1 & -4.4 \\
\hline Eurozone & -22.0 & -16.6 \\
\hline Emerging economies & -12.8 & -15.8 \\
\hline China & -7.7 & -13.8 \\
\hline Emerging Asian countries (excluding China) & -13.1 & -17.2 \\
\hline Eastern Europe and Commonwealth of Independent States (CIS) & -13.4 \\
\hline Latin America and the Caribbean & -4.4 & -27.4 \\
\hline Africa and the Middle East & -13.9 & -2.5 \\
\hline
\end{tabular}

Source: Economic Commission for Latin America and the Caribbean (ECLAC), on the basis of Netherlands Bureau of Economic Policy Analysis (CPB), World Trade Monitor [online database] https://www.cpb.nl/en/worldtrademonitor. 
Global value chains were the main channel for transmitting the effects of COVID-19 to global trade. The measures adopted by China in January (the temporary closure of Hubei Province and national borders) meant that exports of inputs for industries such as the automotive, electronics, pharmaceutical and medical supplies industries, were suspended. This forced factories in North America, Europe and the rest of Asia to shut down for several weeks because they had no alternative suppliers, as China is the world's leading exporter of parts and components, accounting for $15 \%$ of global shipments by 2018 .

- Since March 2020, China has gradually reopened its economy and taken steps to normalize exports. However, the initial supply shock on global trade was gradually compounded by a demand shock, the result of measures to limit the spread of COVID-19 adopted in Europe and later in North America and the rest of the world.

- The volume of global goods trade shrank by around $18.5 \%$ in the second quarter of 2020 compared to the same period in 2019 (WTO, 2020a). Thus, the drop during the first six months is expected to be around $11 \%$. This suggests that the contraction in global trade in 2020 will be closer to the "optimistic" end of the projections that range from $-13 \%$ (similar to the annual fall in $\mathbf{2 0 0 9}$ ) to $\mathbf{- 3 2} \%$ forecast in April. These projections clearly depend on how the pandemic evolves during the second half of the year, particularly in the United States, where infection rates continue to rise.

- Trade in services has also been severely affected. The value of exports from a group of 37 countries, which in 2019 accounted for around two thirds of global exports of services, shrank by $10.4 \%$ in the first quarter of 2020 compared to the same period in 2019. Tourism, which accounted for $\mathbf{2 4 \%}$ of global exports of services in $\mathbf{2 0 1 9}$, has been hit particularly hard. Between January and April 2020, international tourist arrivals declined by $44 \%$ worldwide, compared to the same period in 2019. For 2020 as a whole, arrivals are expected to drop by between $58 \%$ and $78 \%$, depending on how the pandemic evolves and how quickly travel restrictions are relaxed (UN WTO, 2020).

\section{B. The region's trade in goods plummeted $17 \%$ between January and May 2020}

The value of exports and imports of goods decreased by $17 \%$ between January and May 2020 compared to the same period in 2019. Both flows collapsed towards the end of the five-month period in 2020, with a 37\% year-on-year fall in May. The year-on-year drop in trade volume in April and May 2020 was much greater than in the same period in 2009, during the financial crisis: the volume of exports and imports plunged $-20 \%$ and $-25 \%$, respectively (see figure 3 ). The fall in exports was the result of both a supply shock (the partial closure of the productive apparatus) and a demand shock (economic downturn in the region's main markets). In the case of imports, the decline is largely attributable to the deep recession the region is going through, with GDP expected to decline by $9.1 \%$ (ECLAC, 2020a). 
Figure 3 Latin America and the Caribbean: year-on-year change in exports and imports of goods by volume, price and value, January 2007-May 2020

(Percentages)

\section{A. Exports}

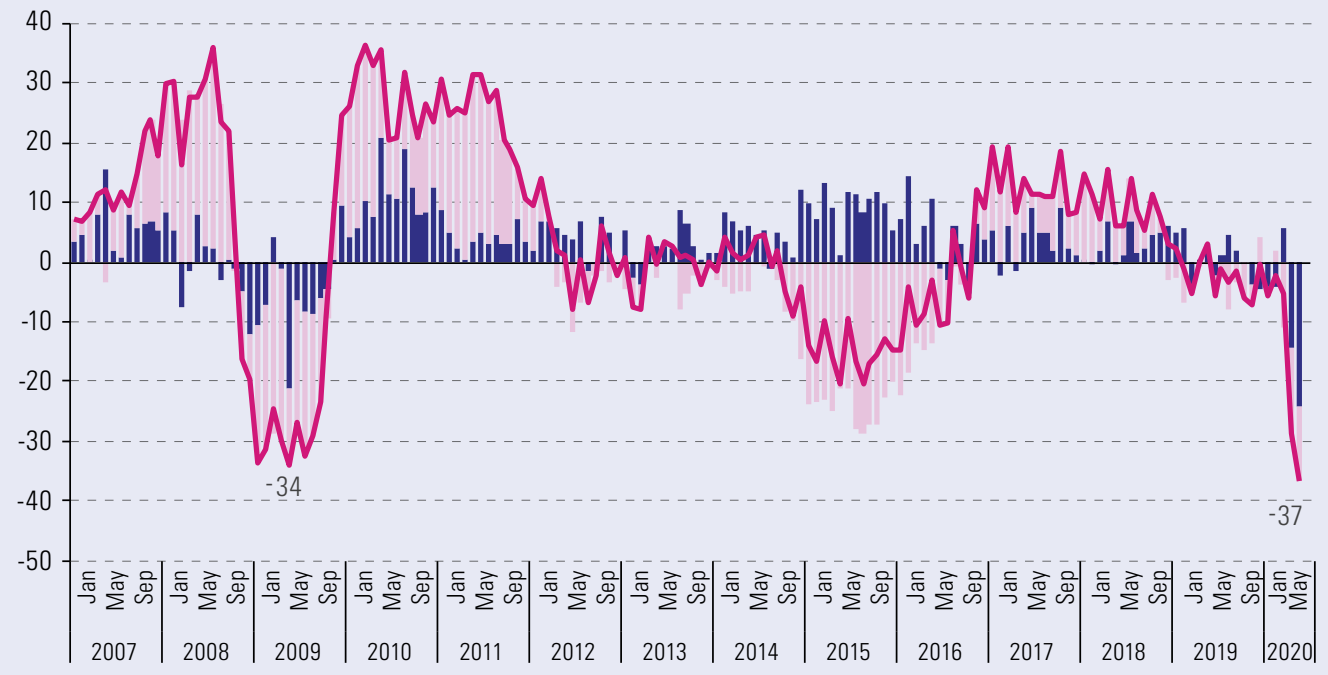

B. Imports

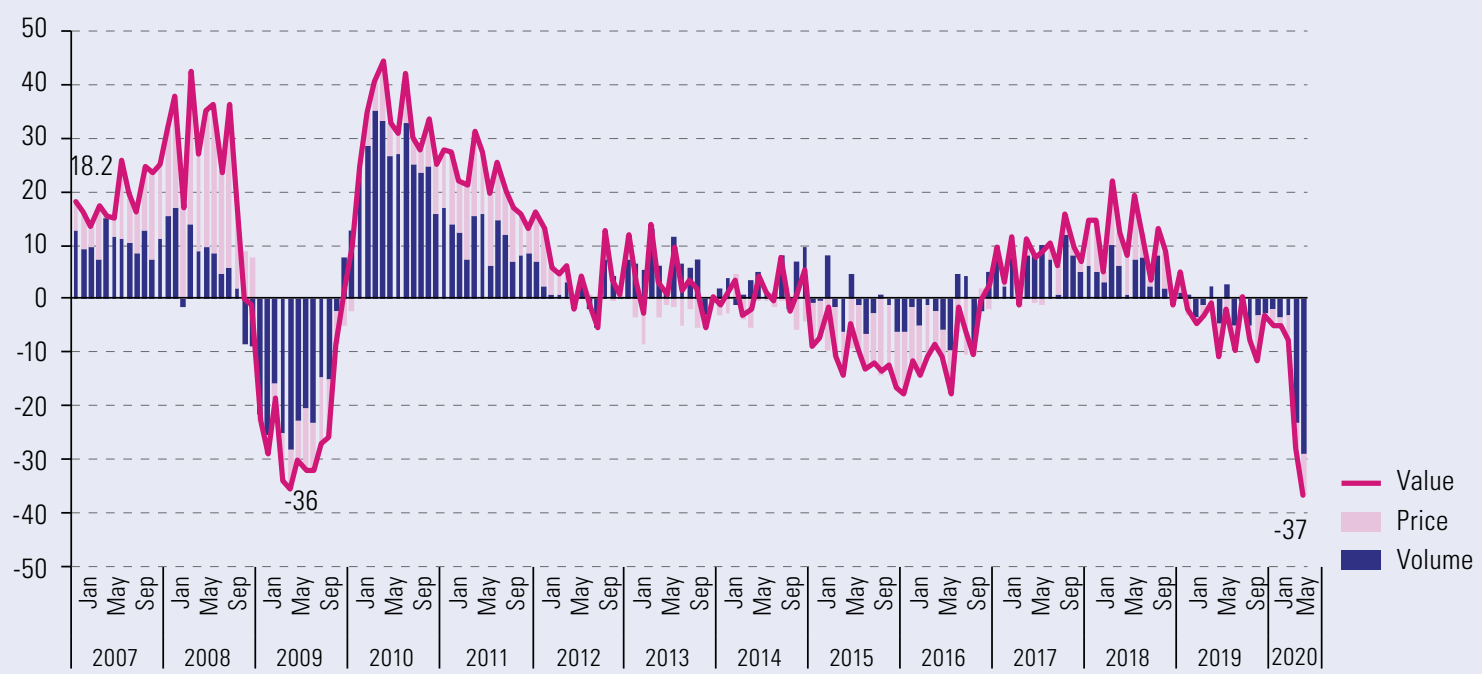

Source: Economic Commission for Latin America and the Caribbean (ECLAC), on the basis of information from the countries' central banks, customs services and institutes of statistics.

\section{Export trends by country and integration blocs}

The fall in the value of regional goods exports between January and May 2020 is explained by an $\mathbf{8 . 6 \%}$ drop in volume and an $\mathbf{8} \%$ decline in prices, which have exacerbated the loss of export momentum that began in 2019 (see table 2). In that year, shipments were hit by the effects of trade tensions between the United States and China and by the low prices of minerals and metals.

- The Andean Community saw the largest average drop in export value (-23\%), owing to the high proportion of energy and mining products in its export basket (63\% on average in 2018-2019). Between December 2019 and May 2020, the prices of all energy products saw double-digit falls, and the prices of several mining products also tumbled.

- The value of Mexico's goods exports plummeted $20.8 \%$ between January and May 2020, mainly

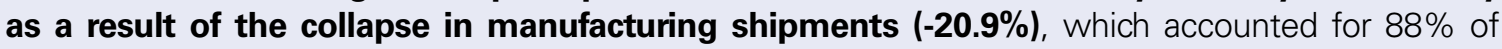
the value exported in that period. Only the exports of the agricultural sector and extractive activities (excluding oil) showed slight increases, 3.5\% and 5.2\%, respectively. The contraction in exports, culminating in a year-on-year decline of $57 \%$ in May, was exacerbated by the severe recession in 
the United States. In May, the value of automotive exports fell at an annualized rate of $90 \%$, while shipments by the electronics, plastics, and machinery and equipment industries shrank by $52 \%, 51 \%$ and $42 \%$, respectively (INEGI, 2020).

Table 2 | Latin America and the Caribbean: year-on-year change in the value of goods exports, January-May 2018-2020, and April and May 2020

(Percentages)

\begin{tabular}{|c|c|c|c|c|c|}
\hline Region/Subregion/Country & $\begin{array}{c}\text { January-May } \\
2018 \\
\end{array}$ & $\begin{array}{c}\text { January-May } \\
2019 \\
\end{array}$ & $\begin{array}{c}\text { January-May } \\
2020 \\
\end{array}$ & April 2020 & May 2020 \\
\hline Latin America and the Caribbean & 10.7 & -0.3 & -16.6 & -29.5 & -37.1 \\
\hline Southern Common Market (MERCOSUR) & 5.8 & -4.1 & -12.4 & -11.7 & -16.2 \\
\hline Argentina & 7.0 & 3.2 & -11.5 & -18.4 & -15.9 \\
\hline Brazil & 6.6 & -2.1 & -6.5 & -5.8 & -13.1 \\
\hline Paraguaya $^{\mathrm{a}}$ & 7.5 & -18.4 & -8.2 & -18.8 & -11.2 \\
\hline Uruguay & 4.5 & 1.0 & -21.4 & -21.0 & -38.1 \\
\hline Venezuela (Bolivarian Republic of) & -1.0 & -27.0 & -65.0 & -53.1 & -47.7 \\
\hline Andean Community & 16.6 & -2.8 & -23.1 & -52.8 & -41.4 \\
\hline Bolivia (Plurinational State of) & 24.3 & -8.7 & -23.8 & -62.1 & -58.5 \\
\hline Colombia & 14.5 & 0.4 & -25.0 & -52.3 & -40.6 \\
\hline Ecuador & 13.6 & 3.1 & -15.2 & -44.4 & -27.2 \\
\hline Peru & 18.5 & -7.3 & -25.3 & -56.3 & -36.3 \\
\hline Pacific Alliance ${ }^{b}$ & 13.9 & 1.7 & -19.8 & -37.6 & -49.4 \\
\hline Chile & 21.3 & -6.6 & -8.8 & -6.3 & -15.2 \\
\hline Mexico & 12.2 & 4.3 & -20.8 & -40.7 & -56.7 \\
\hline Central American Common Market (MCCA) & 2.5 & -1.8 & 0.4 & -13.9 & -8.0 \\
\hline Costa Rica & 7.0 & 1.3 & 2.2 & -11.6 & -3.6 \\
\hline El Salvador & 5.2 & -1.0 & -23.6 & -51.0 & -31.3 \\
\hline Guatemala & -1.3 & -1.9 & 3.2 & -8.1 & -1.6 \\
\hline Honduras & -1.2 & -8.5 & 2.3 & -3.5 & -5.7 \\
\hline Nicaragua & 0.0 & -4.1 & 14.1 & 14.7 & 14.6 \\
\hline Panamac & 11.7 & 0.7 & -11.5 & -30.8 & -52.3 \\
\hline Caribbean countries & 11.2 & 4.5 & -10.0 & -32.1 & -33.3 \\
\hline Cuba & -32.1 & 9.5 & -29.8 & -38.3 & -51.6 \\
\hline Dominican Republic & 7.8 & 4.9 & -8.5 & -27.4 & -28.4 \\
\hline Caribbean Community (CARICOM) & 17.5 & 4.0 & -9.7 & -34.2 & -35.2 \\
\hline
\end{tabular}

Source: Economic Commission for Latin America and the Caribbean (ECLAC), on the basis of information from the countries' central banks, customs services and institutes of statistics, and International Monetary Fund (IMF), Direction of Trade Statistics [online database] https://data.imf. org/?sk=9D6028D4-F14A-464C-A2F2-59B2CD424B85 (for data for Cuba, Panama and CARICOM).

Note: The figures for Cuba, the CARICOM countries, the Dominican Republic and Panama for the months of April and May 2020 are estimates.

a Excludes re-exports.

${ }^{b}$ Covers the four member States. Data for Colombia and Peru are presented under the Andean Community.

c Excludes re-exports from the Colón Free Zone.

- The value of exports from the Southern Common Market (MERCOSUR) decreased by $12.4 \%$ between January and May 2020. The largest drops were in the Bolivarian Republic of Venezuela $(-65 \%)$ and Uruguay $(-21.4 \%)$. The fall in the Bolivarian Republic of Venezuela is explained in large part by the sharp drop in oil prices. In Uruguay, it is largely attributable to the decline in sales of industrial and agricultural manufactures, with figures for products such as furniture, iron and steel and vehicles, which are mainly sold within MERCOSUR, plummeting by over $80 \%$ (CIU, 2020). In Argentina and Brazil, the largest decreases were in manufacturing exports (vehicles, auto parts, chemicals), as a result of lower intraregional demand, and in fuel shipments. However, both countries saw an uptick in their exports of agricultural products (meat, dairy products, soybeans, fruits, sugar), mainly to China and other Asian countries (INDEC, 2020; Ministry of the Economy of Brazil, 2020).

Within the region, goods exports grew in just four countries, all Central American, between January and May 2020. Costa Rica benefited from the increased demand for medical devices to deal 
with the pandemic, especially from the United States. Meanwhile, Guatemala and Honduras expanded their exports of personal protection equipment, especially masks, and of agricultural products. Nicaragua capitalized on the rise in the price of gold and in the volumes of agricultural and livestock products exported (including coffee, sugar cane, beans and tobacco). The economic resilience of these countries can be partly explained by the importance of trade within their own subregion, which helped to offset the lower demand from their extraregional partners. Central America has the highest coefficient of intraregional trade in Latin America and the Caribbean, reaching 29.8\% in 2018 (SIECA, 2019).

Between January and May there were sharp falls in the value of exports from Latin America and the Caribbean to the United States and the European Union, and within the region itself, which together absorbed 69\% of the region's total exports of goods in 2019. However, shipments to Asia have shown greater resilience. In particular, exports to China fell by less than $\mathbf{2} \%$ between January and May, and recovered in April and May 2020, which coincides with the gradual reopening of the Chinese economy (see table 3).

Table 3 Latin America and the Caribbean: year-on-year change in the value of goods exports by destination, January-May 2018-2020, and April and May 2020

(Percentages)

\begin{tabular}{lccccc}
\hline Destination & $\begin{array}{c}\text { January-May } \\
\mathbf{2 0 1 8}\end{array}$ & $\begin{array}{c}\text { January-May } \\
\mathbf{2 0 1 9}\end{array}$ & $\begin{array}{c}\text { January-May } \\
\mathbf{2 0 2 0}\end{array}$ & April 2020 & May 2020 \\
\hline World & $\mathbf{1 0 . 7}$ & $-\mathbf{- 0 . 3}$ & -16.6 & $-\mathbf{2 9 . 5}$ & $\mathbf{- 3 7 . 1}$ \\
\hline United States & 6.6 & 4.9 & -22.2 & -40.5 & -56.0 \\
\hline European Union & 18.7 & -4.5 & -14.3 & -22.8 & -31.2 \\
\hline Asia & 14.9 & 2.4 & -4.2 & -1.3 & -6.1 \\
\hline China & 19.0 & 0.2 & -1.2 & 3.8 & 3.8 \\
\hline Rest of Asia & 10.3 & 5.1 & -6.6 & -11.3 & -22.0 \\
\hline Latin America and the Caribbean & 12.5 & -9.8 & -23.9 & -38.8 & -37.4 \\
\hline
\end{tabular}

Source: Economic Commission for Latin America and the Caribbean (ECLAC), on the basis of information from the countries' central banks, customs services and institutes of statistics.

The value of exports within the region fell by more than the average between January and May 2020 (-24\%), owing to weak demand amid a severe downturn (see figure 4). The contraction in intraregional trade has been particularly evident in manufacturing. The sector that has been hit hardest is the automotive sector, with a fall of around $55 \%$ in the value of trade between January and May 2020, followed by the textiles, apparel and footwear sector. Only trade in agro-industrial products saw modest growth (see figure 5).

Figure 4 | Latin America and the Caribbean: year-on-year change in the value of intraregional goods exports, January 2007-May 2020

(Percentages)

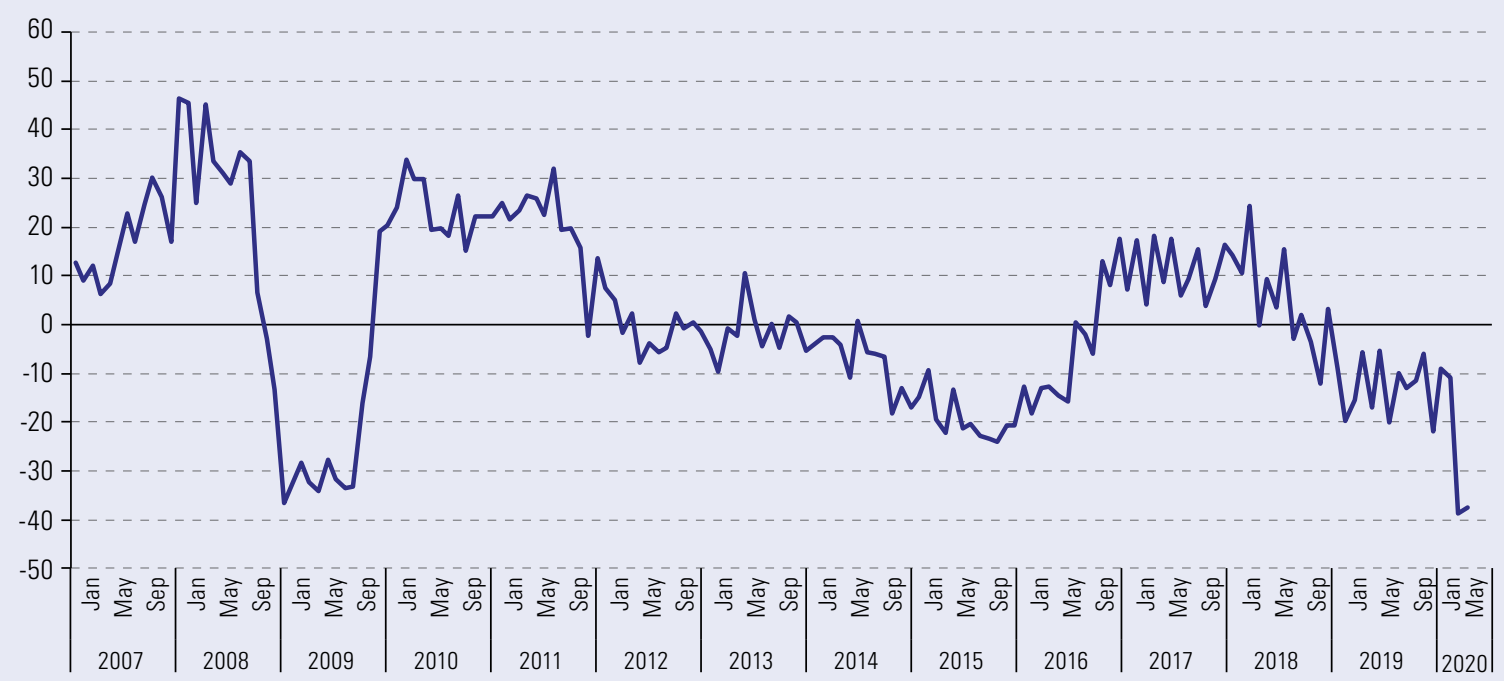

Source: Economic Commission for Latin America and the Caribbean (ECLAC), on the basis of information from the countries' central banks, customs services and institutes of statistics. 
Figure 5 | Latin America and the Caribbean: year-on-year change in the value of intraregional exports by sector, January-May 2020

(Percentages)

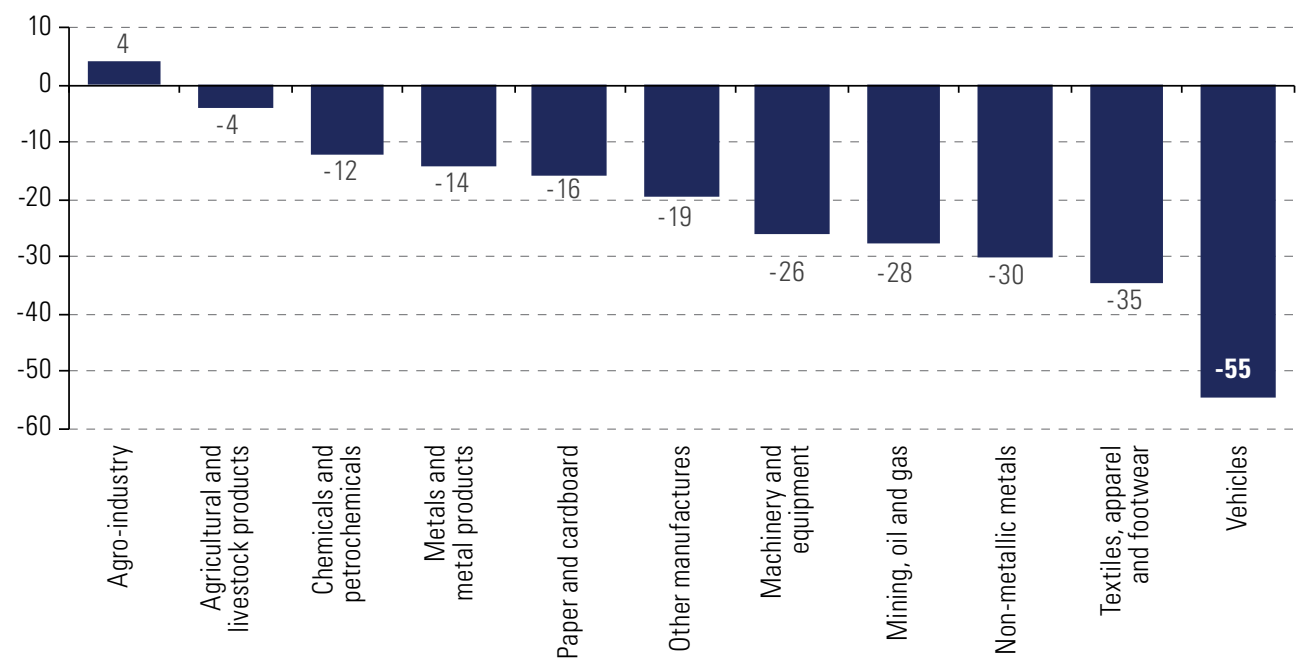

Source:Economic Commission for Latin America and the Caribbean (ECLAC), on the basis of information from the countries' central banks, customs services and institutes of statistics.

- Intraregional trade contracted in all the main economic integration blocs. Between January and May 2020, the value of trade within almost all of them recorded year-on-year declines of between $20 \%$ and $31 \%$. The only exception was trade among the members of the Central American Common Market (MCCA), which showed greater resilience, falling by just 5.6\% (see table 4).

Table 4 | Latin America and the Caribbean: year-on-year variation in intraregional exports within various integration blocs, January-May 2019 and January-May 2020

(Percentages)

\begin{tabular}{|c|c|c|c|c|}
\hline \multirow{2}{*}{ Region or integration bloc } & \multicolumn{2}{|c|}{ Variation } & \multicolumn{2}{|c|}{$\begin{array}{l}\text { Intraregional trade ratio } \\
\text { measured by exports }\end{array}$} \\
\hline & $\begin{array}{c}\text { January-May } \\
2019\end{array}$ & $\begin{array}{c}\text { January-May } \\
2020^{a}\end{array}$ & $\begin{array}{c}\text { January-May } \\
2019\end{array}$ & $\begin{array}{c}\text { January-May } \\
2020\end{array}$ \\
\hline Latin America and the Caribbean & -9.8 & -23.9 & 13.7 & 12.5 \\
\hline Southern Common Market (MERCOSUR) & -19.7 & -22.8 & 11.0 & 9.0 \\
\hline Andean Community & -2.6 & -28.9 & 7.3 & 7.3 \\
\hline Central American Common Market (MCCA) & -1.5 & -5.6 & 27.4 & 24.7 \\
\hline Pacific Alliance & -3.2 & -19.9 & 2.8 & 2.7 \\
\hline Caribbean Community (CARICOM)(January-April) & $\ldots$ & -31.2 & 11.4 & 7.4 \\
\hline
\end{tabular}

Source: Economic Commission for Latin America and the Caribbean (ECLAC), on the basis of information from the countries' central banks, customs services and institutes of statistics, and International Monetary Fund (IMF), Direction of Trade Statistics [online database] https://data.imf. org/?sk=9D6028D4-F14A-464C-A2F2-59B2CD424B85 (for data for CARICOM).

a Preliminary figures.

\section{Export trends by sector}

Between January and May, the value of regional exports of mining products and oil and of manufactures plummeted by $\mathbf{2 5 . 8} \%$ and $\mathbf{1 8 . 5 \%}$, respectively, compared to the same period in 2019. By contrast, agricultural and livestock exports increased by $\mathbf{0 . 9 \%}$ (see table 5 and figure 6). This reflects the lower sensitivity of demand for food to the contraction of economic activity, as food products are essential goods.

- In the case of mining products and oil, the contraction in export value is explained by lower export volumes (a consequence of lower demand) and significant price decreases. The decline in manufacture exports is mainly attributable to lower traded volumes owing to supply shocks (paralysis of industries such as the automotive industry) and demand shocks (recession in the main markets of those products). 
Table 5 | Latin America and the Caribbean: year-on-year change in the value of goods exports by major economic sector, January-May 2018-2020 and April and May 2020

(Percentages)

\begin{tabular}{lcccccc}
\hline Sector & $\begin{array}{c}\text { Share of the } \\
\text { total (2019) }\end{array}$ & $\begin{array}{c}\text { January-May } \\
\mathbf{2 0 1 8}\end{array}$ & $\begin{array}{c}\text { January-May } \\
\mathbf{2 0 1 9}\end{array}$ & $\begin{array}{c}\text { January-May } \\
\mathbf{2 0 2 0}\end{array}$ & April & May \\
\hline All sectors & 100.0 & 10.7 & -0.3 & -16.6 & -29.5 & -37.1 \\
\hline $\begin{array}{l}\text { Agricultural and } \\
\text { livestock products }\end{array}$ & 13.4 & 3.8 & 2.7 & 0.9 & -5.2 & -4.2 \\
\hline Mining and oil & 20.8 & 17.5 & -5.1 & -25.8 & -41.6 & -43.0 \\
\hline Manufactures & 65.8 & 10.3 & 1.0 & -18.5 & -31.2 & -43.1 \\
\hline
\end{tabular}

Source: Economic Commission for Latin America and the Caribbean (ECLAC), on the basis of information from the countries' central banks, customs services and institutes of statistics.

Figure 6 | Latin America and the Caribbean: year-on-year change in the value of goods exports by major economic sector, January 2007-May 2020

(Percentages)

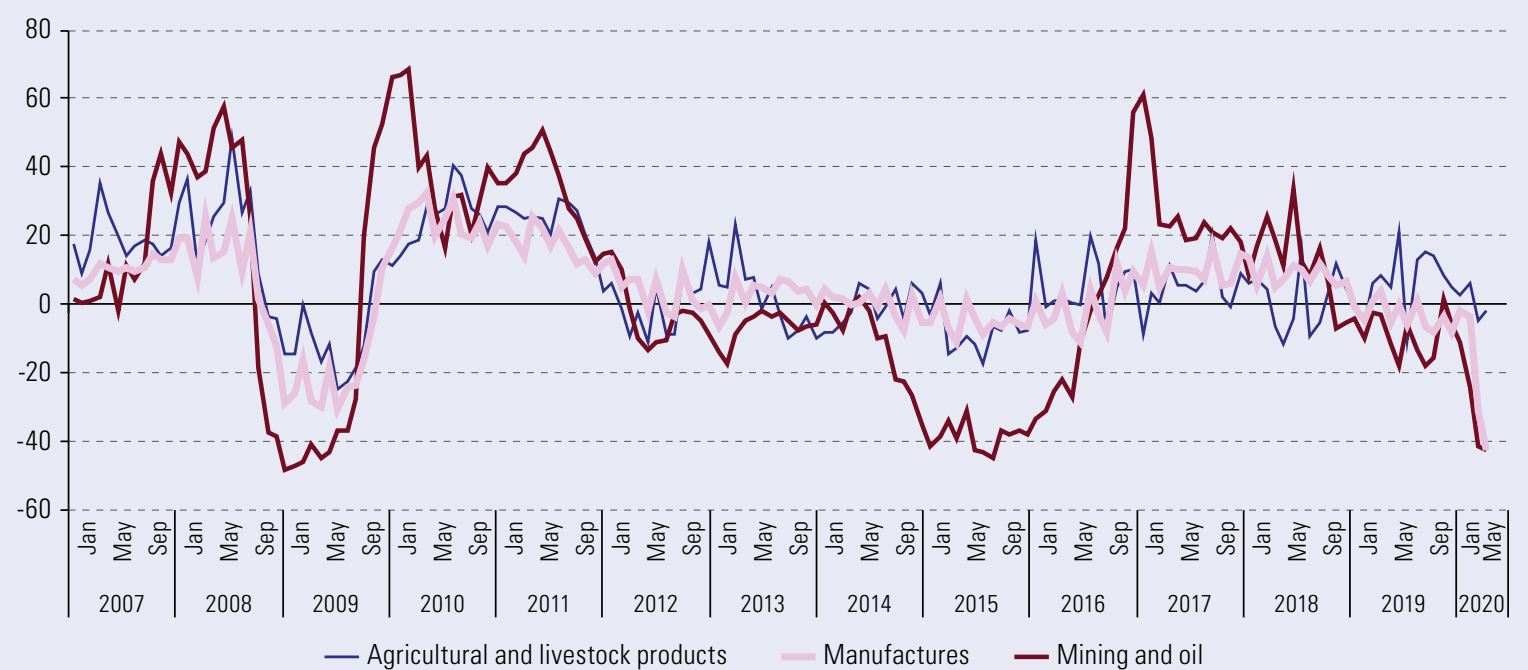

Source: Economic Commission for Latin America and the Caribbean (ECLAC), on the basis of information from the countries' central banks, customs services and institutes of statistics.

- In the case of agricultural and livestock products, Argentina, Brazil, Paraguay and Uruguay benefited from the decrease in sales from Australia to China, mainly because of the drought in Australia, which reduced grain production. MERCOSUR countries also benefited from the increase in beef and pork imports into China to secure food supplies.

- The commodity price index (which includes products that accounted for almost $40 \%$ of the value of the region's total goods exports in 2018 and 2019) plummeted by 18.2\% in January-June 2020 (see table 6). The decline was much greater in energy products (37\%), especially oil and its derivatives.

- The price of oil fell to historic lows in April. At a certain point West Texas Intermediate (WTI) traded below zero on the futures market, against the backdrop of a sharp fall in global demand and a price war between some major producers. Following a decline of up to 66\% in April-May, to around US\$ 30 per barrel, the price has rebounded slightly but remains volatile.

Mineral and metal prices have also suffered from lower expectations for global demand. Until June, most of these products recorded price decreases of between $10 \%$ and $17 \%$. Future trends depend fundamentally on the reactivation of steel and metallurgical production and of construction in China. Only the prices of gold and iron ore increased in the first half of the year. The gold price rose mainly because of its status as a store of value, while the increase in the iron ore price since the second half of May resulted from an outbreak of the pandemic in the Itabira complex of the Vale group. Given that Brazil accounts for $70 \%$ of the supply of iron ore transported by sea, the impact was immediate in June, with a rise of $10 \%$ compared to the closing price in December. The price is expected to fall again once operations resume. 
Among agricultural and livestock products, prices have dropped less than the average for the other commodities, while the prices of bananas and of shrimp and crustaceans have increased.

Table 6 | Latin America and the Caribbean: change in the prices of major export commodities, and projected change for 2020 (Percentages)

\begin{tabular}{|c|c|c|c|}
\hline & $\begin{array}{l}\text { Share of total } \\
\text { goods exports }\end{array}$ & $\begin{array}{c}\text { Change from } \\
\text { December } 2019 \text {-June } 2020\end{array}$ & $\begin{array}{l}\text { Projected change } \\
\text { for } 2020\end{array}$ \\
\hline Total commodities & 39.4 & -18.2 & -18.5 \\
\hline Energy & 14.7 & -37.0 & -39.3 \\
\hline Oil & 11.2 & -37.5 & -40.2 \\
\hline Oil products & 2.0 & -48.0 & -42.7 \\
\hline Natural gas & 1.0 & -22.7 & -30.7 \\
\hline Coal & 0.5 & -11.5 & -21.8 \\
\hline Minerals and metals & 9.4 & -1.9 & -6.1 \\
\hline Other minerals and metals & 2.6 & -13.4 & -16.2 \\
\hline Copper & 2.5 & -7.0 & -12.6 \\
\hline Gold & 2.0 & 14.9 & 15.9 \\
\hline Iron & 1.3 & 10.1 & -9.5 \\
\hline Aluminium & 0.5 & -10.9 & -14.8 \\
\hline Nickel & 0.1 & -22.5 & -17.7 \\
\hline Tin & 0.1 & -3.3 & -14.5 \\
\hline Agricultural and livestock products & 15.3 & -10.1 & -5.9 \\
\hline Soybean oil & 2.1 & -21.2 & -7.8 \\
\hline Bananas & 2.4 & 13.0 & 11.2 \\
\hline Beef & 2.1 & -15.5 & -5.1 \\
\hline Soybeans & 1.9 & -11.1 & -9.3 \\
\hline Coffee & 1.3 & -19.6 & -9.2 \\
\hline Sugar & 1.2 & -22.0 & -11.4 \\
\hline Fishmeal & 1.0 & 1.3 & -5.1 \\
\hline Maize & 1.0 & 1.8 & -5.5 \\
\hline Shrimp and crustaceans & 0.7 & -6.1 & 4.3 \\
\hline
\end{tabular}

Source: Economic Commission for Latin America and the Caribbean (ECLAC), on the basis of data from Bloomberg, The Economist Intelligence Unit, Buenos Aires Grain Exchange, Chilean Copper Commission (COCHILCO) and Agrarian Research and Policy Office of Chile (ODEPA).

\section{Import trends}

Between January and May 2020, the value of the region's goods imports fell by $17.1 \%$, owing to a $12 \%$ drop in volume and a $5 \%$ reduction in prices. Foreign purchases declined in all categories of goods, with the contraction worsening throughout the period (see table 7 and figure 7). Fuel imports recorded the largest decline $(-34 \%)$ as a result of the drop in fuel prices. All other categories decreased by more than $10 \%$. Of particular concern is the contraction in imports of capital goods and intermediate inputs $(-14.5 \%$ and $-13.6 \%$, respectively), which is expected to affect investment and jeopardize the recovery.

Table 7 | Latin America and the Caribbean: year-on-year change in the value of goods imports by broad economic category, January-May 2018-2020 and April and May 2020

(Percentages)

\begin{tabular}{lcccccc}
\hline Category & $\begin{array}{c}\text { Share of total } \\
(\mathbf{2 0 1 9 )}\end{array}$ & $\begin{array}{c}\text { January-May } \\
\mathbf{2 0 1 8}\end{array}$ & $\begin{array}{c}\text { January-May } \\
\mathbf{2 0 1 9}\end{array}$ & $\begin{array}{c}\text { January-May } \\
\mathbf{2 0 2 0}\end{array}$ & April & May \\
\hline All categories & $\mathbf{1 0 0 . 0}$ & $\mathbf{1 3 . 5}$ & -1.3 & $\mathbf{- 1 7 . 1}$ & $\mathbf{- 2 8 . 0}$ & $\mathbf{- 3 7 . 0}$ \\
\hline Capital goods & 14.6 & 17.1 & -5.2 & -14.5 & -29.4 & -22.9 \\
\hline Intermediate inputs & 54.8 & 10.1 & 0.9 & -13.6 & -16.9 & -37.0 \\
\hline Consumer goods & 18.2 & 11.7 & -3.9 & -17.1 & -31.3 & -39.1 \\
\hline Fuels & 12.5 & 33.0 & 4.7 & -34.0 & -59.2 & -63.7 \\
\hline
\end{tabular}

Source: Economic Commission for Latin America and the Caribbean (ECLAC), on the basis of information from the countries' central banks, customs services and institutes of statistics. 
Figure 7 | Latin America: year-on-year change in the value of goods imports by broad economic category, January 2007-May 2020

(Percentages)

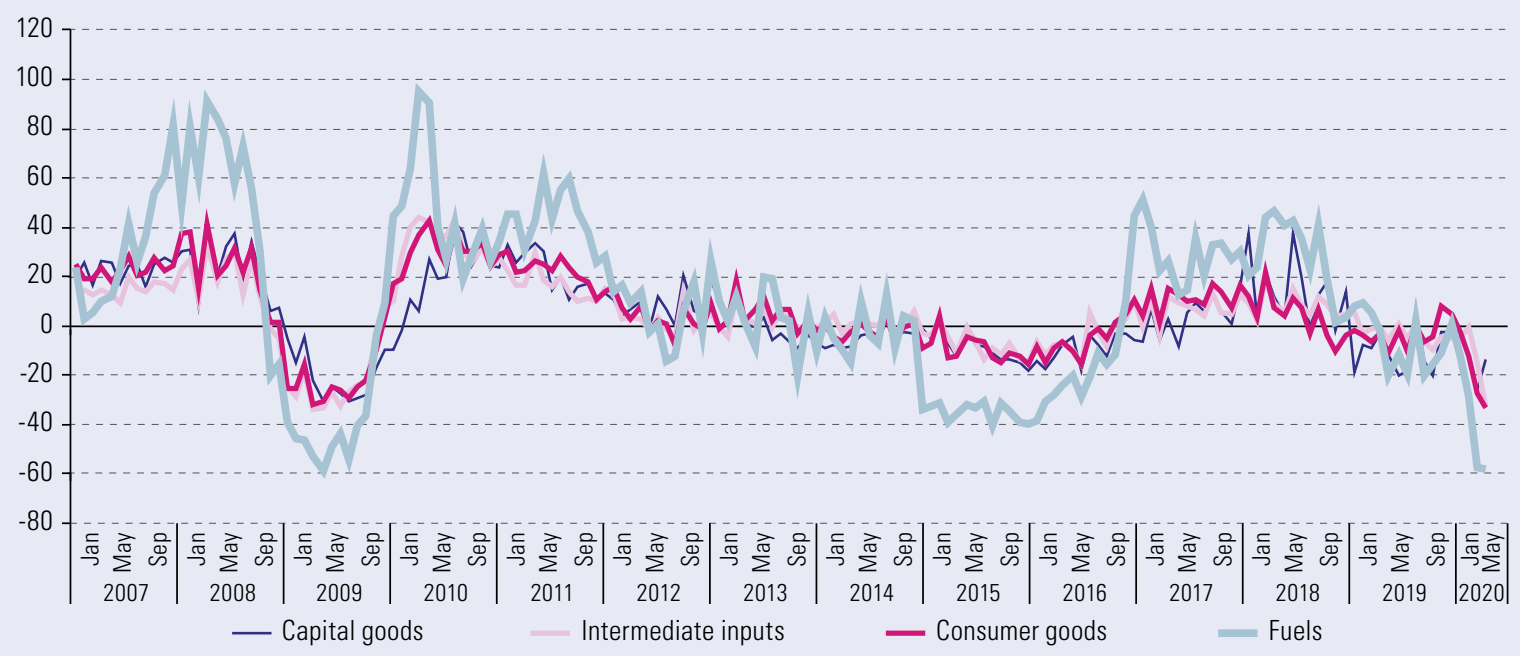

Source: Economic Commission for Latin America and the Caribbean (ECLAC), on the basis of information from the countries' central banks, customs services and institutes of statistics.

- The value of imports shrank in all countries of the region (see table 8) as a result of the recession. Unlike exports, imports from all major supplier countries contracted sharply (see table 9).

Table 8 | Latin America and the Caribbean: year-on-year change in the value of goods imports, January-May 2018-2020 and April and May 2020

(Percentages)

\begin{tabular}{|c|c|c|c|c|c|}
\hline Region/Subregion/Country & $\begin{array}{c}\text { January-May } \\
2018\end{array}$ & $\begin{array}{c}\text { January-May } \\
2019\end{array}$ & $\begin{array}{c}\text { January-May } \\
2020\end{array}$ & April 2020 & May 2020 \\
\hline Latin America and the Caribbean & 13.5 & -1.3 & -17.1 & -28.0 & -37.0 \\
\hline MERCOSUR & 18.3 & -10.1 & -8.9 & -20.3 & -17.1 \\
\hline Argentina & 18.8 & -28.7 & -23.8 & -30.1 & -31.8 \\
\hline Brazil & 18.0 & 1.8 & -2.5 & -14.8 & -10.5 \\
\hline Paraguay & 20.1 & -7.2 & -19.9 & -50.7 & -36.1 \\
\hline Uruguay & 12.5 & -10.1 & -6.3 & -18.8 & -17.5 \\
\hline Venezuela (Bolivarian Republic of) & 22.0 & -56.8 & -45.1 & -36.3 & -42.0 \\
\hline Andean Community & 11.3 & 3.2 & -20.5 & -34.4 & -42.9 \\
\hline Bolivia (Plurinational State of) & 5.2 & 7.3 & -37.7 & -63.3 & -61.0 \\
\hline Colombia & 6.0 & 5.2 & -17.8 & -28.4 & -45.4 \\
\hline Ecuador & 23.1 & 4.5 & -25.2 & -41.3 & -48.9 \\
\hline Peru & 13.4 & -0.7 & -18.5 & -31.8 & -36.9 \\
\hline Pacific Alliance & 12.4 & 1.7 & -19.3 & -29.6 & -44.6 \\
\hline Chile & 16.9 & -0.5 & -20.5 & -22.7 & -36.4 \\
\hline Mexico & 12.3 & 1.9 & -19.0 & -30.5 & -47.1 \\
\hline Central American Common Market & 9.0 & -2.5 & -14.0 & -25.4 & -22.6 \\
\hline Costa Rica & 6.0 & -1.3 & -9.1 & -18.6 & -15.1 \\
\hline El Salvador & 11.3 & 6.2 & -18.0 & -32.9 & -45.2 \\
\hline Guatemala & 10.0 & 1.9 & -7.5 & -16.0 & -18.1 \\
\hline Honduras & 10.6 & -0.5 & -14.9 & -28.9 & -22.5 \\
\hline Nicaragua & 4.9 & -21.4 & -28.2 & -43.9 & -31.2 \\
\hline Panama $^{a}$ & 10.5 & -11.0 & -25.7 & -32.0 & -37.4 \\
\hline Caribbean countries & 7.7 & 7.1 & -25.8 & -35.9 & -44.8 \\
\hline Cuba & 6.9 & -2.1 & -40.7 & -57.1 & -41.3 \\
\hline Dominican Republic & 11.6 & 4.7 & -21.5 & -29.9 & -48.5 \\
\hline Caribbean Community (CARICOM) & 5.5 & 11.0 & -25.1 & -33.8 & -43.1 \\
\hline
\end{tabular}

Source: Economic Commission for Latin America and the Caribbean (ECLAC), on the basis of information from the countries' central banks, customs services and institutes of statistics, and International Monetary Fund (IMF), Directorate of Trade Statistics [online database] https://data.imf. org/?sk=9D6028D4-F14A-464C-A2F2-59B2CD424B85 (for data for Cuba, the Dominican Republic and CARICOM).

Note: The figures for Cuba, the CARICOM countries, the Dominican Republic and Panama for the months of April and May 2020 are estimates.

a Excluding the Colón Free Zone. 
Table 9 | Latin America and the Caribbean: year-on-year change in the value of goods imports by origin, January-May 2018-2020 and April and May 2020

(Percentages)

\begin{tabular}{lccccc}
\hline & $\begin{array}{c}\text { January-May } \\
\mathbf{2 0 1 8}\end{array}$ & $\begin{array}{c}\text { January-May } \\
\mathbf{2 0 1 9}\end{array}$ & $\begin{array}{c}\text { January-May } \\
\mathbf{2 0 2 0}\end{array}$ & April 2020 & May 2020 \\
\hline World & $\mathbf{1 3 . 5}$ & -1.3 & -17.1 & $\mathbf{- 2 8 . 0}$ & $-\mathbf{3 7 . 0}$ \\
\hline United States & 10.6 & -0.5 & -19.6 & -38.2 & -48.7 \\
\hline European Union & 23.3 & -5.3 & -18.1 & -23.1 & -39.0 \\
\hline Asia & 13.4 & 5.2 & -16.0 & -21.8 & -34.2 \\
\hline China & 17.0 & 6.0 & -17.4 & -21.4 & -33.4 \\
\hline Other Asian countries & 9.0 & 4.1 & -14.1 & -22.2 & -35.0 \\
\hline Latin America and the Caribbean & 11.8 & -7.8 & -25.1 & -34.5 & -42.4 \\
\hline
\end{tabular}

Source: Economic Commission for Latin America and the Caribbean (ECLAC), on the basis of information from the countries' central banks, customs services and institutes of statistics.

\section{The collapse in tourism is dragging down services exports}

In the first quarter of 2020, the value of service exports and imports for a group of 11 countries in the region fell by $\mathbf{1 0 . 2 \%}$ and $\mathbf{9 \%}$, respectively, compared to the same period in 2019 (see table 10). ${ }^{2}$ As with trade in goods, trade in services declined over the quarter (see figure 8). However, the collapse in the value of trade in services in these countries was far greater than that in goods trade, which recorded decreases of $2.7 \%$ and $4.6 \%$ in exports and imports, respectively.

- Travel recorded the largest decline in exports in regional services between January and March 2020 (-17.4\%), owing to the virtual halt in international tourist arrivals (see figure 9). This segment was followed by transport services, which fell by $6.8 \%$ amid the contraction in regional goods trade and the restrictions to contain the pandemic. Exports of other services shrank the least $(-2.4 \%)$, with some items in this category even recording an increase. Physical distancing measures have increased the demand for digital services, such as communication, shopping, education, medical and entertainment services (WTO, 2020b).

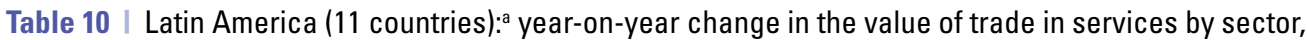
first quarter of 2019 and first quarter of 2020

(Percentages)

\begin{tabular}{|c|c|c|c|c|}
\hline \multirow[b]{2}{*}{ Sector } & \multicolumn{2}{|c|}{ Exports } & \multicolumn{2}{|c|}{ Imports } \\
\hline & $\begin{array}{c}\text { January-March } \\
2019\end{array}$ & $\begin{array}{c}\text { January-March } \\
2020\end{array}$ & $\begin{array}{c}\text { January-March } \\
2019 \\
\end{array}$ & $\begin{array}{c}\text { January-March } \\
2020\end{array}$ \\
\hline Total services & 0.0 & -10.2 & -6.1 & -9.0 \\
\hline 1. Transport & 2.4 & -6.8 & -3.3 & -7.5 \\
\hline 2. Travel & 1.5 & -17.4 & -15.0 & -25.4 \\
\hline 3. Other services & -3.0 & -2.4 & 3.7 & -0.1 \\
\hline $\begin{array}{l}\text { Communications, computer } \\
\text { and information services }\end{array}$ & 3.4 & 2.3 & -2.5 & 17.3 \\
\hline Construction services & 6.8 & -1.6 & -55.3 & -39.0 \\
\hline Insurance services & 1.7 & 0.0 & 12.2 & -0.4 \\
\hline Financial services & 6.4 & 24.3 & 19.6 & -4.1 \\
\hline Royalties and licence fees & -19.8 & -3.1 & -10.0 & -11.5 \\
\hline Other business services & -7.2 & -0.8 & -7.9 & -2.6 \\
\hline Personal, cultural and recreational services & 26.8 & 8.6 & $\ldots$ & 13.8 \\
\hline
\end{tabular}

Source: Economic Commission for Latin America and the Caribbean (ECLAC), on the basis of official data from the countries' central banks.

a Argentina, Brazil, Chile, Colombia, Costa Rica, Dominican Republic, El Salvador, Mexico, Peru, Plurinational State of Bolivia and Uruguay. These countries account for $78 \%$ and $82 \%$ of the region's exports and imports of commercial services, respectively. 
Figure 8 | Latin America (11 countries): ${ }^{\text {a }}$ year-on-year change in the value of trade in services, first quarter of 2007-first quarter of 2020

(Percentages)

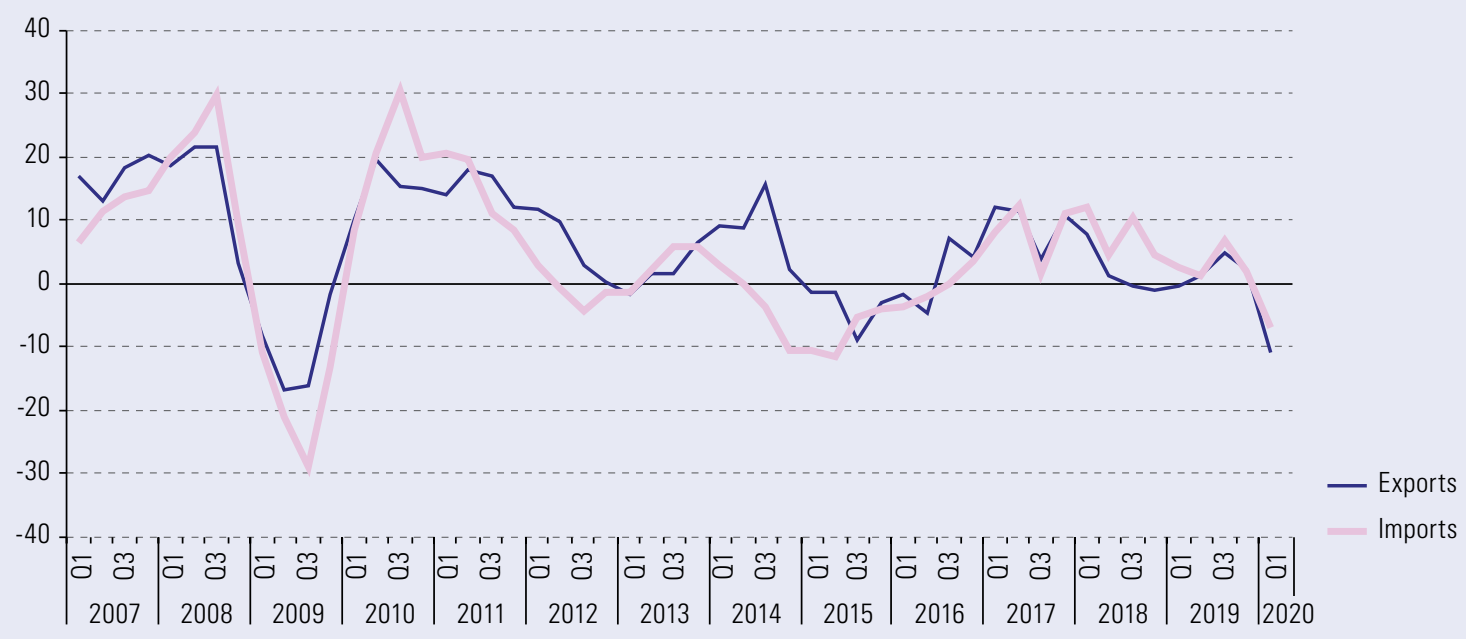

Source: Economic Commission for Latin America and the Caribbean (ECLAC), on the basis of data from the countries' central banks.

a Argentina, Brazil, Chile, Colombia, Costa Rica, Dominican Republic, El Salvador, Mexico, Peru, Plurinational State of Bolivia and Uruguay.

Figure 9 | Latin America and the Caribbean (selected countries): year-on-year change in international tourist arrivals, January 2018-May 2020

(Percentages)

\section{A. South American countries}

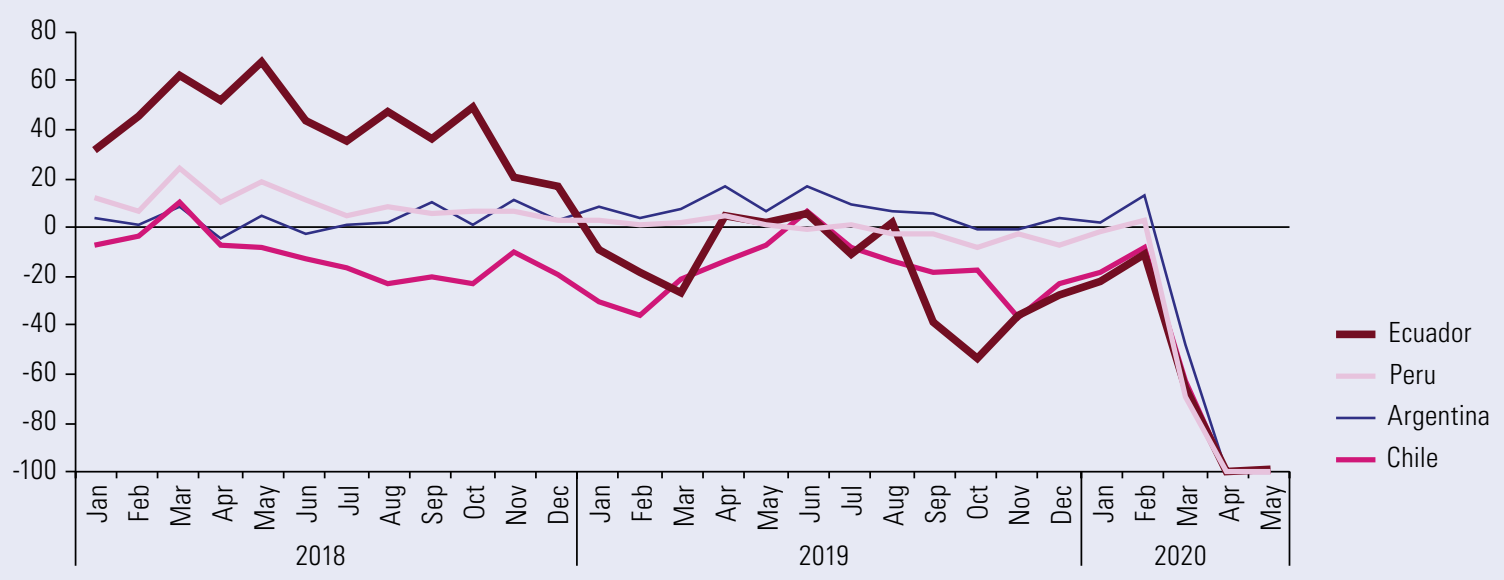

\section{B. Other countries}

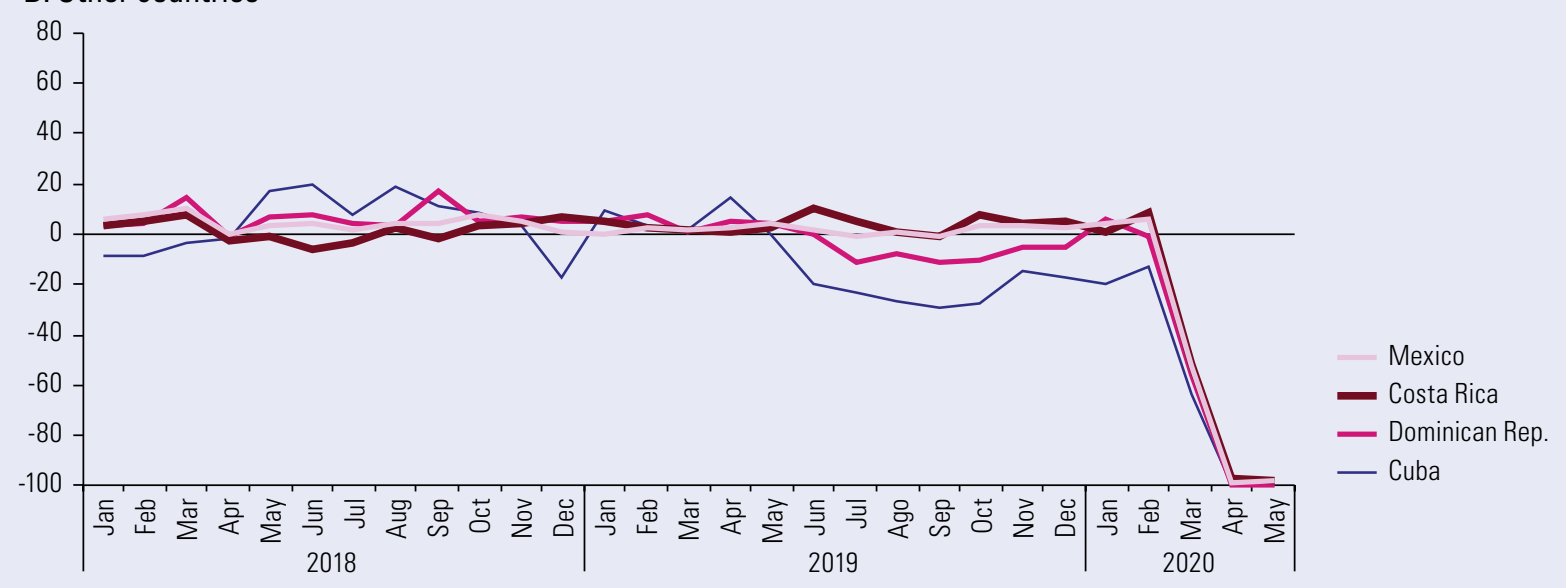

Source: Economic Commission for Latin America and the Caribbean (ECLAC), on the basis of official information. 
- The paralysis of tourism is critical for the region as this sector accounted for $48 \%$ of the value of total exports of services in 2019, twice the share of tourism in global service exports. The situation is particularly worrying for Caribbean countries, where tourism accounted for $45 \%$ of total exports of goods and services in 2019. In this context, the value of Caribbean exports of goods and services is projected to fall by $40 \%$ in 2020 (see figure 10). Meanwhile, GDP and total employment could be reduced by around 8 and 9 percentage points, respectively (ECLAC, 2020b).

Figure 10 | Latin America and the Caribbean (selected countries and subregions): projected decline in exports, GDP and employment, 2020

A. Goods and services exports

(percentages)

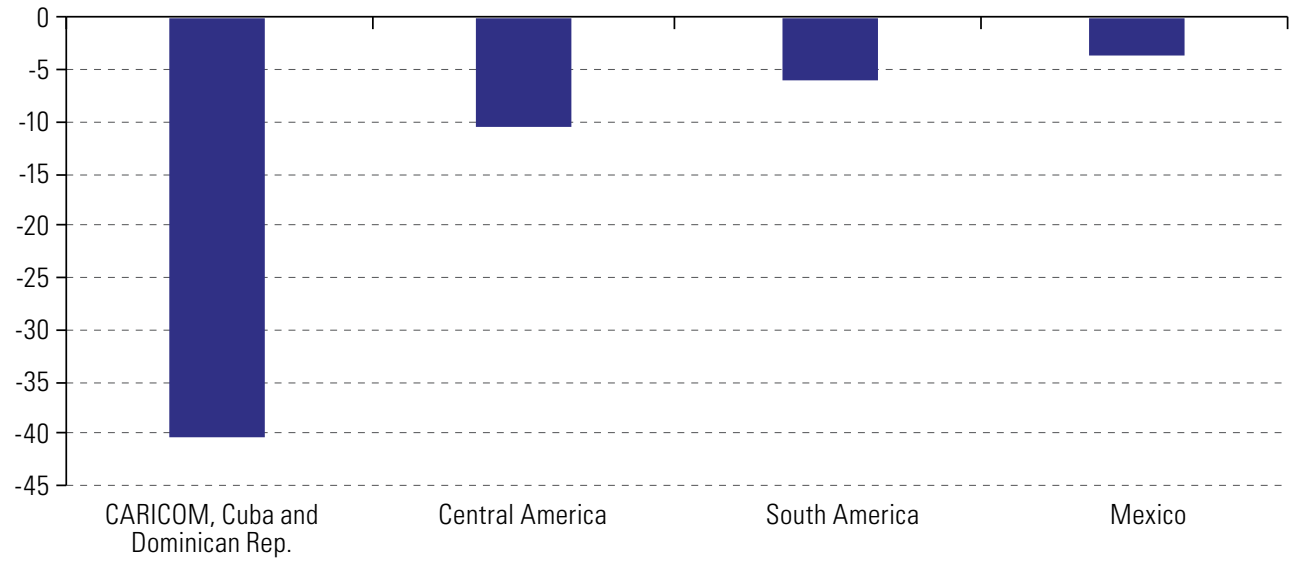

B. GDP and employment (percentage points)

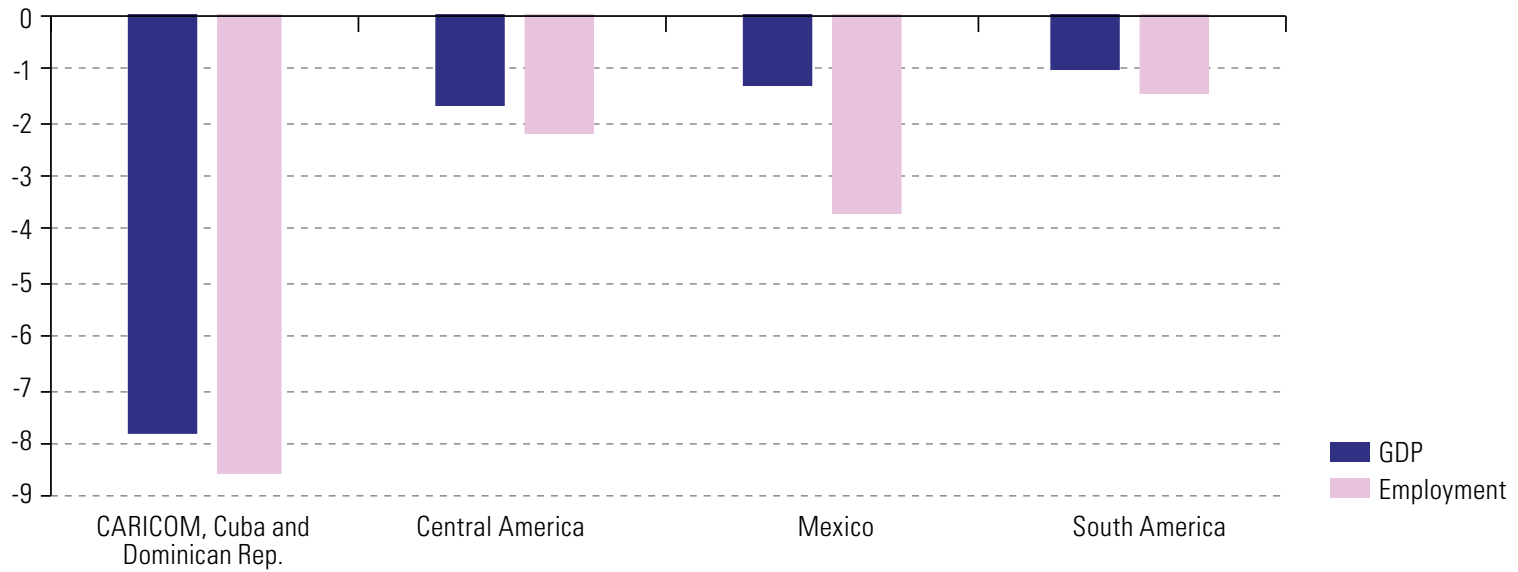

Source: Economic Commission for Latin America and the Caribbean (ECLAC), "Recovery measures for the tourism sector in Latin America and the Caribbean present an opportunity to promote sustainability and resilience", COVID-19 Reports, Santiago, July 2020.

Note: In this analysis, the Caribbean Community (CARICOM) does not include Montserrat. Central America does not include El Salvador and, in figure 10B, does not include Panama. South America does not include the Bolivarian Republic of Venezuela.

\section{International transport problems hamper regional trade}

Globally, maritime container trade has trended downward since the outbreak of the pandemic. After rising in some regions until February, it fell in the vast majority from March onward (see table 11). In Latin America, the year-on-year change in the period January-May 2020 was $-6.1 \%$, with sharp declines in April and May. 
Table 11 | Year-on-year change in international maritime trade by container, January-May 2020 (Percentages)

\begin{tabular}{lcccccc}
\hline & January & February & March & April & May & January-May \\
\hline Latin America & 3.1 & 2.9 & 2.5 & -16.6 & -20.9 & -6.1 \\
\hline North America & -0.5 & -6.8 & -3.2 & -15.5 & -17.3 & -8.8 \\
\hline Europe & 0.9 & -3.9 & -1.8 & -16.3 & -14.6 & -7.3 \\
\hline Far East & 2.3 & -12.4 & -6.1 & -13.8 & -6.0 & -7.0 \\
\hline $\begin{array}{l}\text { Indian subcontinent } \\
\text { and the Middle East }\end{array}$ & 3.5 & 6.5 & -3.4 & -27.6 & -21.2 & -8.9 \\
\hline World & 1.8 & -6.2 & -3.9 & -15.9 & -11.4 & -7.3 \\
\hline
\end{tabular}

Source: Economic Commission for Latin America and the Caribbean (ECLAC), on the basis of information from Container Trades Statistics (CTS).

Despite the drop in maritime traffic in 2020, container transport rates remained above 2019 values (see figure 11), except during the annual seasonal decline that coincides with the Chinese New Year. From the end of April, rates began to rise steadily, and by 2 July 2020 they were 48\% higher than the previous year. This suggests that the industry was able to manage supply and thus achieve a price level that allowed it to partially offset the decline in demand caused by COVID-19. Despite this, 6 of the 10 largest shipping companies in the world have requested assistance from their home governments: CMA CGM, COSCO Shipping Lines, HMM, Evergreen Marine, Yang Ming and Pacific International Lines (PIL).

Figure 11 | Maritime shipping costs, January-June 2019 and January-June 2020

(Dollars per 40-foot container)

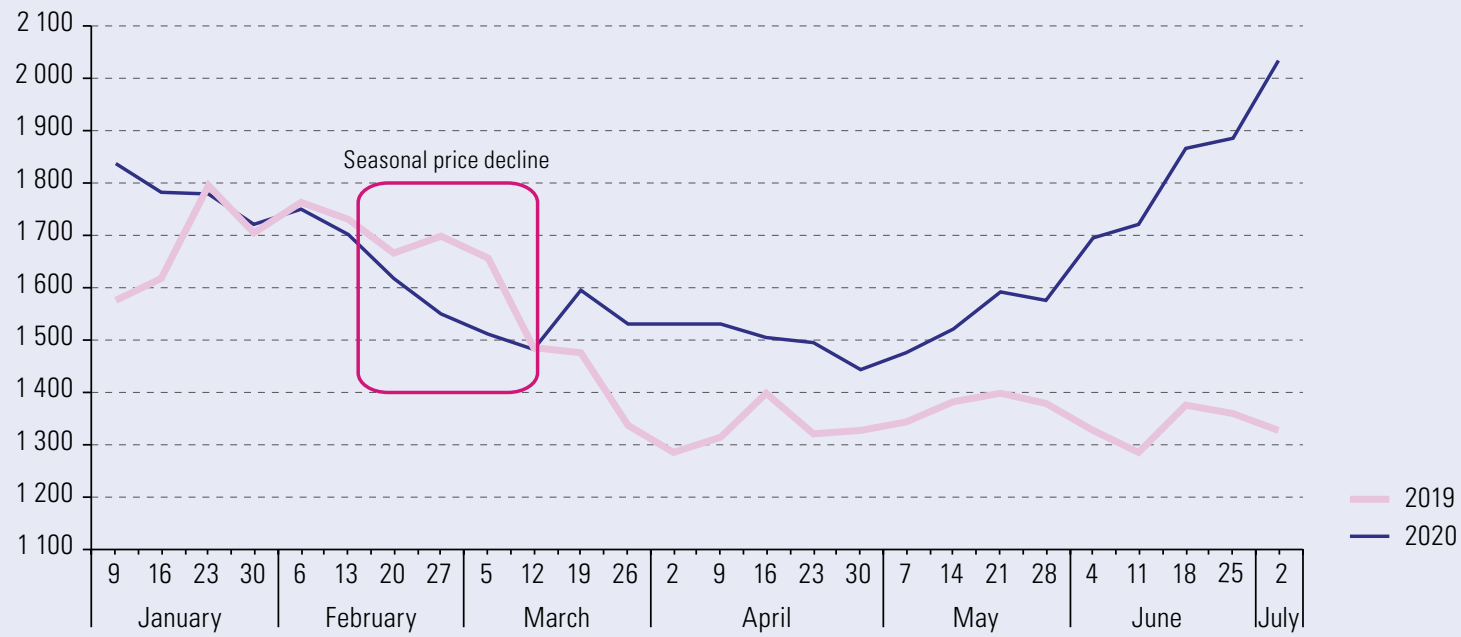

Source: Economic Commission for Latin America and the Caribbean (ECLAC), on the basis of information from Drewry

The outbreak of the pandemic has caused a drop in activity in many of the region's ports. Table 12 shows the year-on-year variation in container port activity between January and May 2020 in a selection of ports that account for $80 \%$ of total cargo in Latin America and the Caribbean. The regional fall in container port activity is around $1 \%$, while in the same period the sum of imports and exports by container declined by $6 \%$. The difference between these two figures is explained by the fact that other operational and trans-shipment movements offset the drop in containerized international trade. Preliminary data collected at the end of June suggests that, during that month, both total container movements and the sum of container imports and exports shrank by an additional 4 percentage points over the contraction seen up to May. 
Table 12 | Latin America and the Caribbean (selected ports): container port activity, January-May 2020 compared to the year-earlier period

(Percentages)

\begin{tabular}{|c|c|c|c|c|}
\hline & $\begin{array}{l}\text { Ports and percentage of port } \\
\text { activity in each country }\end{array}$ & Country & $\begin{array}{c}\text { Share of the regional total } \\
\text { (twenty-foot equivalent } \\
\text { unit (TEU))(2019) }\end{array}$ & $\begin{array}{c}\text { Change from } \\
\text { January-May } 2020\end{array}$ \\
\hline \multicolumn{2}{|c|}{ Ports where activity declined } & \multicolumn{3}{|c|}{43.4} \\
\hline \multirow{13}{*}{ 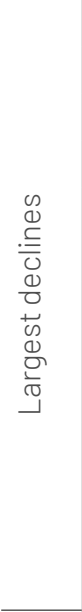 } & Buenaventura (25\%) & Colombia & 2.1 & -32.9 \\
\hline & Valparaíso (31\%) & Chile & 1.7 & -28.0 \\
\hline & Lázaro Cárdenas (19\%) & Mexico & 2.4 & -18.8 \\
\hline & Freeport (85\%) & Bahamas & 2.6 & -16.6 \\
\hline & Caucedo $(67 \%)$ & Dominican Republic & 2.3 & -15.0 \\
\hline & Altamira $(13 \%)$ & Mexico & 1.6 & -14.9 \\
\hline & San Antonio (60\%) & Chile & 3.2 & -10.2 \\
\hline & Veracruz $(16 \%)$ & Mexico & 2.1 & -9.8 \\
\hline & Rio Grande (7\%) & Brazil & 1.4 & -9.5 \\
\hline & Brazil, other $(28 \%)$ & Brazil & 5.3 & -7.0 \\
\hline & Iquique $(6,1 \%)$ & Chile & 0.2 & -6.4 \\
\hline & El Callao $(86 \%)$ & Peru & 4.3 & -5.9 \\
\hline & Manzanillo (42\%) & Mexico & 5.7 & -3.8 \\
\hline \multirow{4}{*}{ 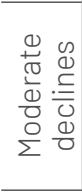 } & Limón-Moin (80\%) & Costa Rica & 2.3 & -2.3 \\
\hline & Buenos Aires (84\%) & Argentina & 2.7 & -1.5 \\
\hline & Kingston (85\%) & Jamaica & 3.0 & -1.1 \\
\hline & Point Lisas (48\%) & Trinidad and Tobago & 0.3 & -0.4 \\
\hline \multicolumn{2}{|c|}{ Ports where activity increased } & \multicolumn{3}{|c|}{36.8} \\
\hline \multirow{7}{*}{ 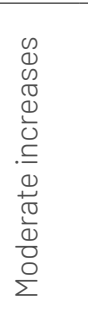 } & Montevideo (100\%) & Uruguay & 1.4 & 0.1 \\
\hline & Itajai $(12 \%)$ & Brazil & 2.3 & 1.9 \\
\hline & Guayaquil (91\%) & Ecuador & 3.6 & 2.6 \\
\hline & Zárate (6\%) & Argentina & 0.3 & 3.2 \\
\hline & Santos $(38 \%)$ & Brazil & 7.2 & 7.1 \\
\hline & Itapoa $(7 \%)$ & Brazil & 1.4 & 8.1 \\
\hline & Paranagua (8\%) & Brazil & 1.6 & 9.3 \\
\hline \multirow{5}{*}{ 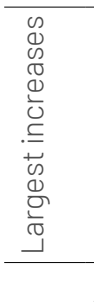 } & Rosario (3\%) & Argentina & 0.1 & 10.5 \\
\hline & Bahía de Cartagena (67\%) & Colombia & 5.4 & 11.7 \\
\hline & $\begin{array}{l}\text { Panama, Caribbean coast, } \\
3 \text { terminals }(60 \%)\end{array}$ & Panama & 8.1 & 14.0 \\
\hline & $\begin{array}{l}\text { Panama, Pacific coast, } \\
2 \text { terminals }(39 \%)\end{array}$ & Panama & 5.3 & 17.4 \\
\hline & All selected ports & & 80.2 & -0.8 \\
\hline
\end{tabular}

Source: Economic Commission for Latin America and the Caribbean (ECLAC), on the basis of information from port authorities and operators.

- The growing concentration of the shipping industry is worrying, given its potential impact on freight rates during the downturn and recovery. In 1992, the shipping market was mainly shared among 30 companies, which accounted for some $63 \%$ of the total fleet. In 1998, six alliances were formed, representing $50 \%$ of the world fleet. Between 2000 and 2010, the combined capacity of the fleet of the top 30 carriers doubled to 10.81 million twenty-foot equivalent units (TEU). By 2018, the combined market share of three of the alliances was nearly $70 \%$ of global supply (capacity) and, by 2020, they have increased their share to $84.2 \%$.

This increasing concentration has led to the vertical integration of ports. For example, at the end of March 2020, integrated terminals handled $68 \%$ of containers in Buenos Aires and $49 \%$ in Brazil, according to ECLAC figures. In the port of Callao (Peru), they moved $41 \%$ of the total and, in the Caribbean, they accounted for $35 \%$ of total trans-shipments. 
- The sudden and prolonged downturn in air traffic puts the aviation industry and its workers at risk and could undermine connectivity in the region. Travel restrictions have meant that aviation has been one of the sectors hit hardest by the pandemic. According to data from the International Civil Aviation Organization (ICAO) Data+, in May 2020 global revenue passenger kilometres (RPK) and freight tonne kilometres (FTK) had fallen $98.9 \%$ and $62.1 \%$ year-on-year, respectively.

- In Argentina, Brazil, Chile and Colombia, falls in May 2020 averaged 95\% (RPK) and 46\% (FTK). The volume of freight transported decreased less in the region than it did worldwide because air logistics account for a small share of the region's international trade. Consequently, in response to growing and pressing demand for essential products some airlines have temporarily converted their passenger planes into cargo carriers, increasing load factors and minimizing the drop.

- Uncertainty over how the pandemic will evolve and the measures that the industry will have to implement to resume its activities, in addition to the already precarious financial situations of many companies before the pandemic, means the airline industry is facing the worst crisis in its history. According to the International Air Transport Association (IATA), airlines' net losses in 2020 could be as much as US\$ 84.3 billion, putting around 32 million jobs at risk (IATA, 2020a). In the first five months of 2020, airlines lost almost half of their global market value, while in the region they lost $70 \%$.

- The severe impact of the pandemic has forced several airlines to request financial support. In total, governments around the world have committed US\$123 billion in financial aid for the sector (IATA, 2020a). In emerging markets, however, the scope of such measures has been relatively limited. Several airlines in the region (Aeroméxico, Avianca and LATAM) have had to begin financial restructuring under Chapter 11 of the United States Bankruptcy Code.

- Aviation is crucial to territorial connectivity, tourism and job creation, so the future of companies in the sector will affect the region's economic performance. The pandemic will affect airline debt levels, and potentially the routes served, flight frequency and service fees. This may well have a negative impact on the connectivity of remote territories and islands, and the affordability of their services, as they depend on air services for transporting residents, cargo and tourists.

- The closure of productive activities, stricter health measures and administrative obstacles have slowed down land transport. Although transport by truck is crucial to meeting demand for essential items, there is less activity as a result of the pandemic. Globally, the annual turnover of companies in the sector is expected to shrink by around 18\% in 2020; in Latin America it is projected to fall by $20 \%$ $(I R U, 2020)$. These projections are in line with the decline in the volume transported seen in the first half of the year (see figure 12).

Figure 12 | Latin America (14 countries): year-on-year change in the volume of goods transported by truck, 2020 (Percentages)

A. Year-on-year change, March-May 2020

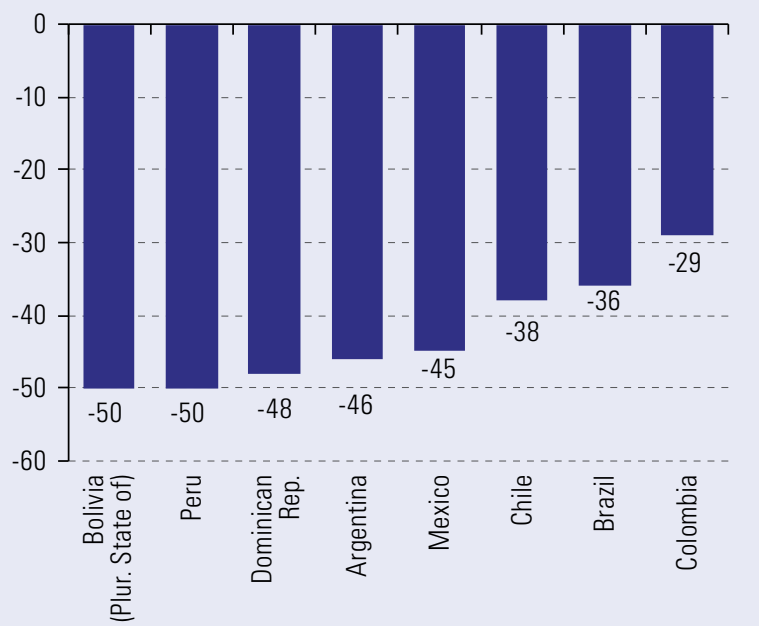

B. Year-on-year change, 25 February-28 June ${ }^{a} 2020$

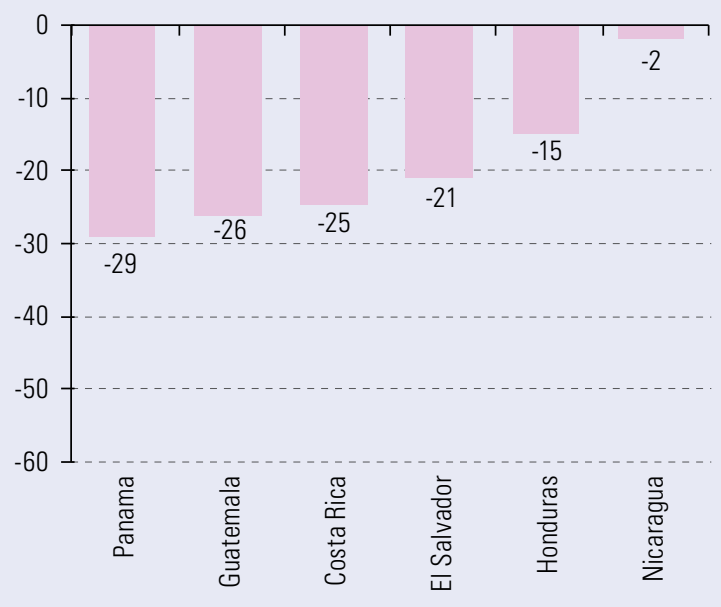

Source: Economic Commission for Latin America and the Caribbean (ECLAC), on the basis of information from the Secretariat for Central American Economic Integration (SIECA) and trucking associations.

${ }^{a}$ Number of land transit declarations per country of origin in the Central American Single Declaration (DUCA) system. 
- The fall in the total volume transported by truck is mainly a result of less economic activity and the standstill in sectors linked to construction, tourism, fuel transport and auto parts. Transport activity has also been driven down by longer operating cycles. Loading, unloading and transit times have increased owing to measures such as health checkpoints on the main transport corridors. Process facilitation problems, lack of awareness of transit protocols and restrictions on the time foreign drivers may remain in each country have all caused further delays. For example, in some cases local authorities have closed road access, banned facilities from providing health services to drivers or even prohibited drivers from leaving their vehicle to eat or respond to a problem with the cargo.

- At the same time as revenues have fallen as a result of the drop in freight, the number of journeys with no backload has increased owing to a lack of cargo at both ends of the supply chain. Payments are also being delayed, reducing the liquidity of hauliers, which are mostly one-person companies or micro-enterprises. The informality that characterizes the sector could mean that hauliers are not eligible for financial assistance for businesses.

- Steps must be taken to facilitate international trade and logistics. Efficient and smooth logistics are essential in ensuring a timely supply of inputs and food, and in limiting distortions and surcharges that disproportionately affect the most vulnerable populations. However, in some cases, restrictive measures have been imposed to stop the disease spreading, which have affected the transit of goods and inputs between neighbouring countries. One example was the closing of borders by Costa Rica in response to the heightened risk of imported cases. Business communities and representatives of hauliers from neighbouring countries immediately warned of the economic impact of the measure. In response, Central American authorities adopted a biosafety protocol for haulage and began implementing coordinated procedures to stop the spread of the coronavirus (see SIECA, 2020).

- Urban logistics and e-commerce have proved vital for the continuity of urban activities, enabling the distribution of the food and goods needed for the long periods of confinement to which large swathes of the population have been subjected. One challenge in this sector is how to protect workers from infection and from widespread job insecurity, especially in the case of migrants. In the medium term, it is crucial to integrate urban logistics into transport policies, reducing the number of trips or making them more efficient (for example, through logistics collaboration and modes of transport with fewer negative externalities, such as electromobility). Steps must also be taken to strengthen the coordination of those efforts with measures concerning territorial development, land use and growing urban density.

\section{E. Exports and imports of goods set to decline by a quarter in 2020}

- In the first half of the year, regional exports and imports of goods are estimated to have fallen in value by $17 \%$ and $18 \%$, respectively. Worsening growth prospects for several of the region's main markets and uncertainty over how the pandemic will evolve mean that a recovery in regional foreign trade in the second half of the year is unlikely.

- The Economic Commission for Latin America and the Caribbean (ECLAC) therefore projects a $23 \%$ contraction in the value of the region's goods exports in 2020 , as a result of declines in both prices $(-11 \%)$ and volumes $(-12 \%)$ (see figure 13$)$. For the value of imports, the expected fall is even larger (-25\%) (see figure 14). The volume of imports could decrease by as much as $18 \%$, slightly more than the drop seen in $\mathbf{2 0 0 9}$, during the global financial crisis, and similar to those observed in 1982, at the beginning of the foreign debt crisis, and 1942, when the fall was caused by Second World War shortages. 
Figure 13 I Latin America and the Caribbean: change in goods exports by value, volume and price, 1930-2019 and projection for 2020

(Percentages)

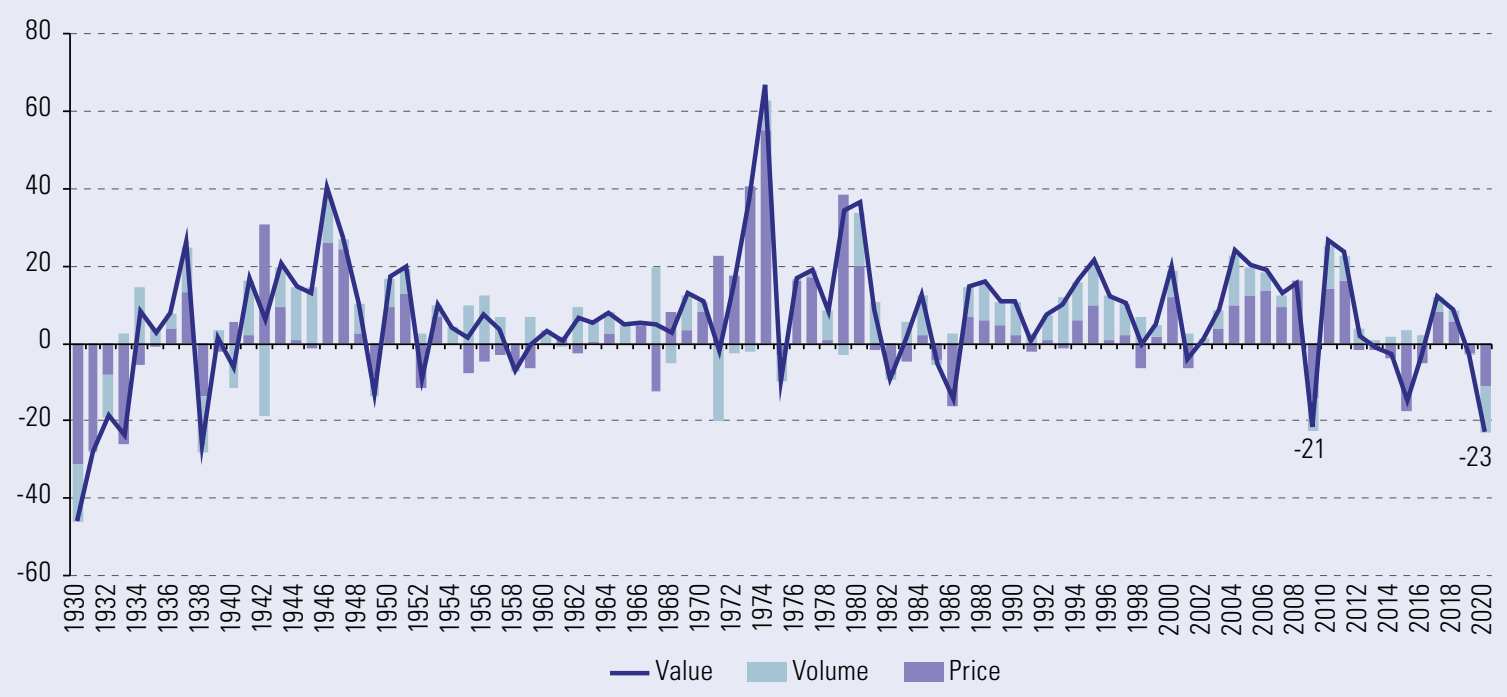

Source: Economic Commission for Latin America and the Caribbean (ECLAC), on the basis of official information on the countries' balance of payments (1980-2019), and ECLAC series for exports at current prices and price indices (1930-1979).

Note: The 2020 figures are ECLAC projections.

Figure 14 I Latin America and the Caribbean: change in goods imports by value, volume and price, 1930-2019 and projection for 2020

(Percentages)

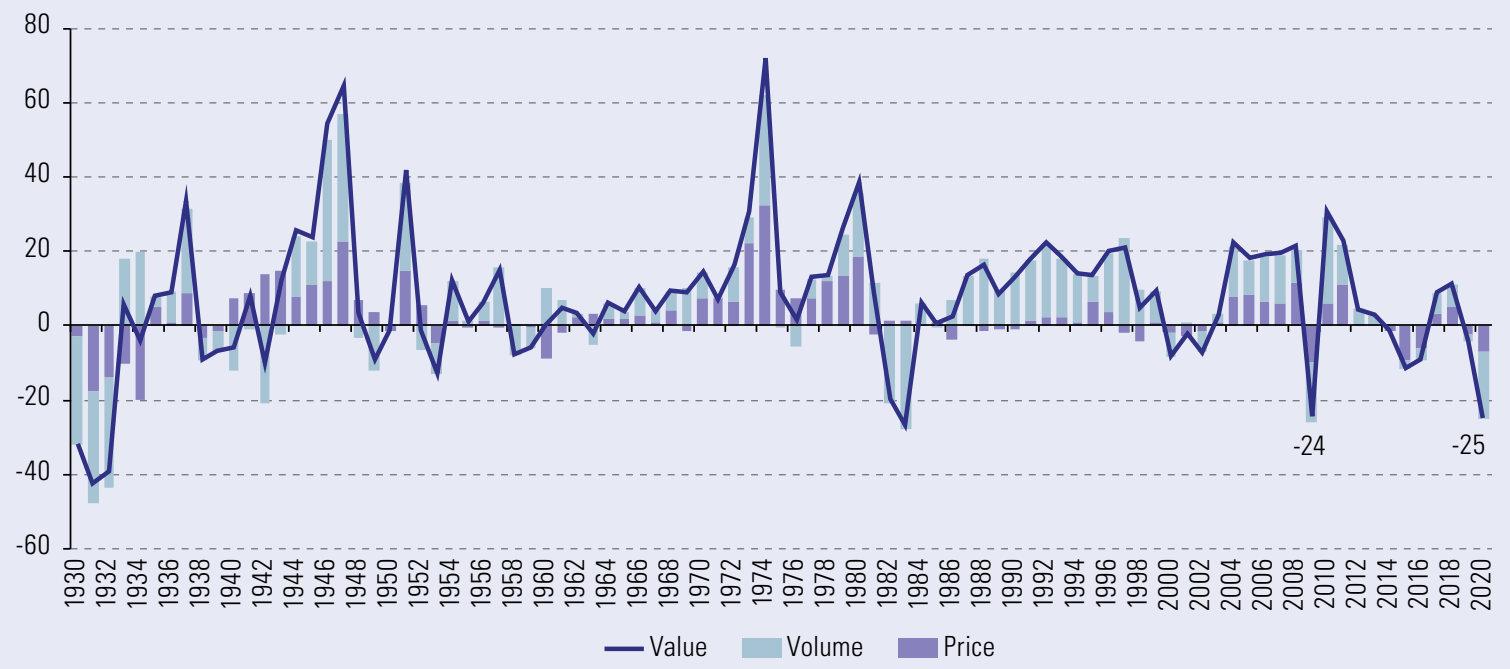

Source: Economic Commission for Latin America and the Caribbean (ECLAC), on the basis of official information on the countries' balance of payments (1980-2019), and ECLAC series for imports at current prices and price indices (1930-1979).

Note: The 2020 figures are ECLAC projections.

The largest contractions in exports in 2020 are expected in those to the United States (-32\%) and to the region itself $(-28 \%)$, while shipments to China are projected to fall by just $\mathbf{4} \%$ (see table 13). Given the structure of exports to these markets -mainly manufactures to the United States and the region, and commodities to China- the net effect would accentuate the reprimarization of the regional export basket. Meanwhile, imports will fall considerably, from all the region's main suppliers.

- In keeping with the trend in exports by destination, the sharpest falls in value are projected for mining and oil, and manufacturing shipments (see table 14). In the case of mining and oil, this is partly a result of a steep drop in prices, while in manufacturing it is mainly because of smaller export volumes. Agricultural and livestock shipments look set to be the most resilient, with a projected increase in value of $\mathbf{2} \%$. Imports are expected to fall across the board, but the largest contraction will be in fuel purchases, owing to the fall in prices. 
Table 13 | Latin America and the Caribbean: projected change in the value of trade in goods by trading partner, 2020 (Percentages)

\begin{tabular}{lcc}
\hline & Exports & Imports \\
\hline World & -23 & -25 \\
\hline United States & -32 & -32 \\
\hline European Union & -16 & -24 \\
\hline Asia & -7 & -23 \\
\hline China & -4 & -27 \\
\hline Other Asian countries & -11 & -19 \\
\hline Latin America and the Caribbean & -28 & -29 \\
\hline
\end{tabular}

Source: Economic Commission for Latin America and the Caribbean (ECLAC), on the basis of information from the countries' central banks, customs services and institutes of statistics.

Table 14 | Latin America and the Caribbean: projected change in the value of trade in goods by sector, 2020 (Percentages)

\begin{tabular}{lc}
\hline & Projected variation \\
\hline Total exports & -23 \\
\hline Agricultural and livestock products & 2 \\
\hline Mining and petroleum & -33 \\
\hline Manufactures & -25 \\
\hline Total imports & -25 \\
\hline Capital goods & -19 \\
\hline Intermediate inputs & -21 \\
\hline Consumer goods & -22 \\
\hline Fuels & -44 \\
\hline
\end{tabular}

Source:Economic Commission for Latin America and the Caribbean (ECLAC), on the basis of information from the countries' central banks, customs services and institutes of statistics.

As imports are forecast to fall more than exports, the region is expected to record a trade surplus of just over US\$ 45 billion in 2020, concentrated in the countries of the Southern Common Market (MERCOSUR), Chile and Mexico. For the Andean Community, whose members have been hit hard by tumbling oil and mineral prices, a trade deficit of just over US\$4.5 billion is projected. The Central American and Caribbean countries are expected to see their deficits shrink significantly compared to 2019 (see figure 15).

Figure 15 | Latin America and the Caribbean (selected groupings and countries): goods trade balance, 2019 and projection for 2020

(Billions of dollars)

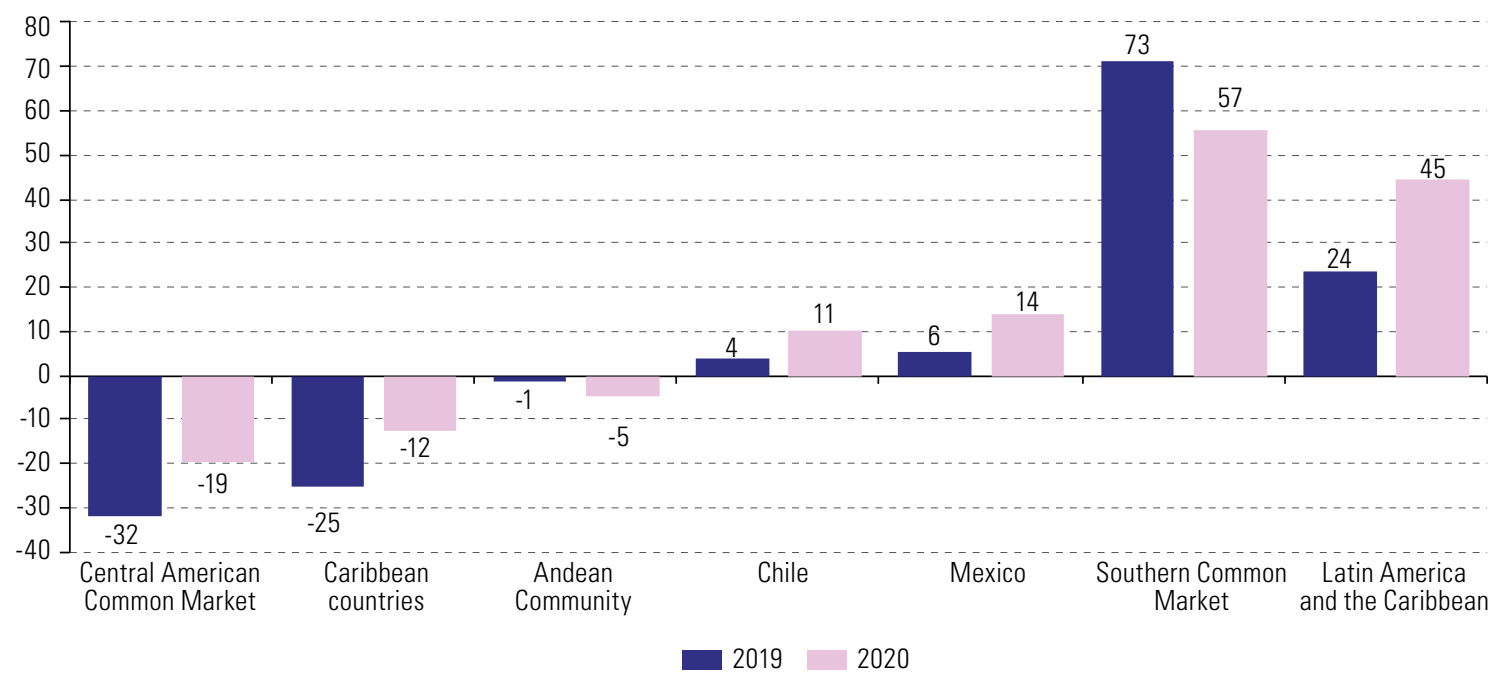

Source: Economic Commission for Latin America and the Caribbean (ECLAC), on the basis of official information. 
The sharp fall in demand in the region is expected to lead to a collapse in intraregional trade in all areas, with double-digit percentage declines in almost all cases (see table 15). This situation will mainly affect manufacture exports, whose main market for almost all countries is the region itself.

Table 15 Latin America and the Caribbean: structure of intraregional trade, average intraregional trade ratio as measured by exports, 2018-2019 and projected variation in $2020^{\text {a }}$

(Billions of dollars and percentages)

\begin{tabular}{lcccc}
\hline Sector & $\begin{array}{c}\text { Intraregional } \\
\text { exports }\end{array}$ & Share & $\begin{array}{c}\text { Intraregional } \\
\text { trade ratio }\end{array}$ & $\begin{array}{c}\text { Projected variation } \\
\text { in 2020 }\end{array}$ \\
\hline Agriculture, hunting, and fishing & 13.521 & 8 & 10 & -2 \\
\hline Oil and mining & 25.998 & 16 & 19 & -15 \\
\hline Food, beverages, and tobacco & 19.139 & 12 & 18 & -14 \\
\hline Wood, pulp, and paper & 5.784 & 4 & 20 & -12 \\
\hline Textiles, apparel, and footwear & 6.804 & 4 & 22 & -18 \\
\hline Chemicals and petrochemicals & 16.505 & 10 & 41 & -24 \\
\hline Medicines & 3.282 & 2 & 59 & -10 \\
\hline Rubber and plastic & 4.643 & 3 & 35 & -24 \\
\hline Non-metallic minerals & 2.408 & 1 & 33 & -23 \\
\hline Metals and related products & 14.383 & 9 & 9 & -27 \\
\hline Machinery and equipment & 16.829 & 10 & 8 & -24 \\
\hline Automotive & 23.418 & 14 & 16 & -45 \\
\hline Other manufactures & 11.820 & 7 & 13 & -33 \\
\hline Total & 164.535 & 100 & 15 & -28 \\
\hline
\end{tabular}

Source: Economic Commission for Latin America and the Caribbean (ECLAC), on the basis of information from UN Comtrade - International Trade Statistics Database.

a Excludes information on the maquila industry in Central America.

- The expected trend in regional foreign trade in 2020 suggests there will be a loss of productive capacity in the industrial sector, linked to the sharp contraction in exports of manufactures and in imports of capital goods and intermediate inputs. This will make it more difficult to move towards a more knowledge-intensive export specialization as the region emerges from the crisis.

\section{F. A more uncertain and regionalized world economy makes further regional integration imperative}

- The pandemic is likely to reinforce two interrelated trends that were already taking shape. The first is a shift towards less interdependence in production, trade and technology among the world's major economies, particularly between the United States and Europe on the one hand, and China on the other. The second is a trend towards world trade that is less open, more influenced by geopolitical and national security considerations, with more frequent disputes and with a weakened multilateral framework. The net result will not be the reversal of globalization, but a more regionalized world economy, organized around three major productive hubs: North America, Europe, and East and South-East Asia.

- In a global context of increased production regionalization, regional integration must play a key role in the crisis-recovery strategies in Latin America and the Caribbean. Establishing an integrated market of 650 million people would provide the countries of the region with significant protection against external supply or demand shocks. It would also help achieve the scale required to strengthen strategic industries such as pharmaceuticals and medical supplies, and to foster shared production and research networks among countries and subregions. This would reduce the region's vulnerability to supply disruptions such as those seen during the pandemic (ECLAC, 2020c). Meanwhile, in a context of weakening multilateralism, greater regional coordination is vital to foster a more equal dialogue with the main actors in the global economy (see diagram 1). 
Diagram 1 | Immediate consequences of COVID-19 for trade and production and opportunities to strengthen regional integration in Latin America and the Caribbean

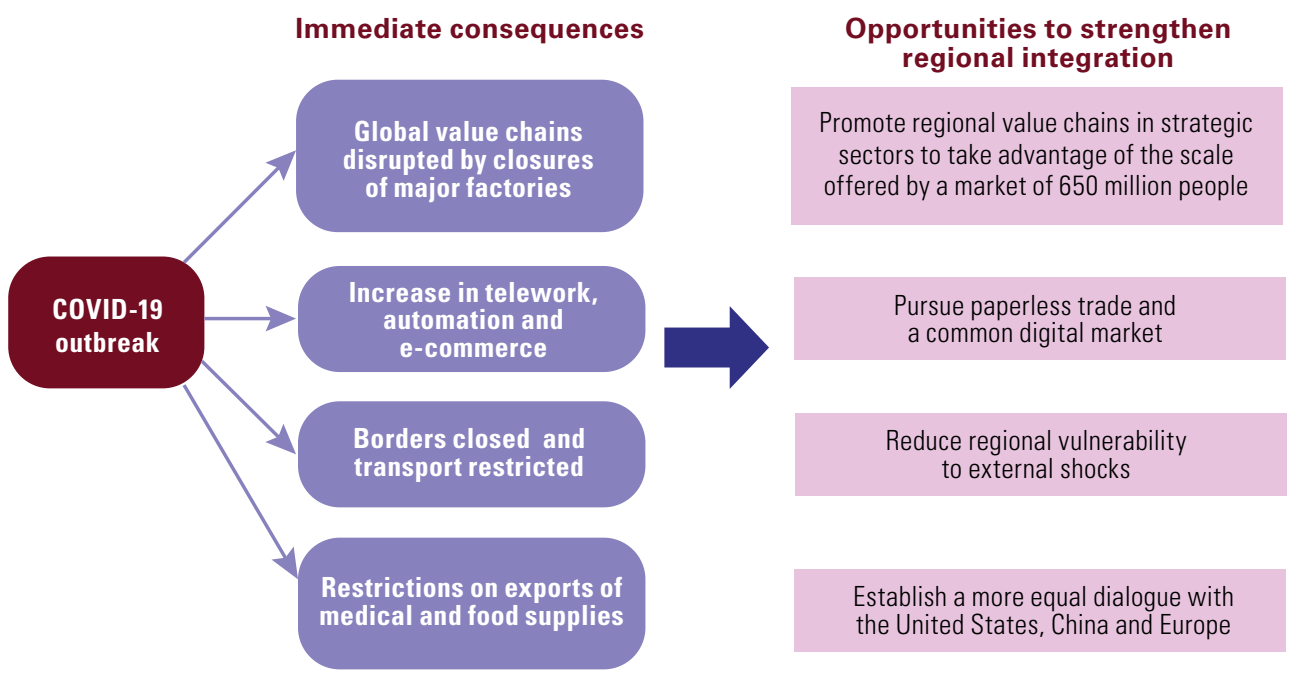

Source: Economic Commission for Latin America and the Caribbean (ECLAC)

- To move forward with regional integration, infrastructure and logistics must be included in economic recovery packages. In addition to their sizeable direct contributions to GDP and employment, infrastructure and logistics are essential for the production of all goods and services, the supply of food and essential services, and international trade competitiveness.

Against the current backdrop of great uncertainty, the countries of the region must act to reduce their internal logistics costs and create value-added services to maintain their competitiveness. These actions must be implemented in a coordinated manner with other economic and social measures, to promote an economic recovery with social and environmental benefits. In the case of infrastructure and logistics, four elements are crucial: investment, interoperability, regional integration and logistics intelligence.

- The current situation is particularly inimical to initiatives to deepen regional integration. In addition to the known differences in terms of strategic vision, there is now a health, economic and social crisis of epic proportions and the threat of a severe food crisis. However, there are unmistakable signs of a major reconfiguration of the global economic geography, and specifically indications of a more important role for regions. Therefore, deeper regional integration must be an essential component of any strategy to overcome the crisis. Given the crucial role of the regional market for manufacture exports and small and medium-sized exporting firms, coordinated action to reactivate intraregional trade can mitigate the loss of business fabric and the reprimarization of the productive and export structure that will be the pandemic's legacy in Latin America and the Caribbean.

\section{Bibliography}

Arias, J. (2020a), “Aumentan 11 \% a mayo 2020 las importaciones agroalimentarias de China, principalmente desde Estados Unidos y Argentina", Inter-American Institute for Cooperation on Agriculture (IICA) Blog, 29 June [online] https://blog.iica.int/index.php/blog/aumentan-12-las-importaciones-agricolas-chinaprincipalmente-desde-alc.

_ (2020b), “Monitoreando el comercio agroalimentario durante el COVID-19", Inter-American Institute for Cooperation on Agriculture (IICA) Blog, 14 July [online] https://blog.iica.int/en/blog/monitoreandocomercio-agroalimentario-durante-covid-19.

CEIE (Centre for Studies on Economic Integration) (2019), Informe Económico Regional 2018-2019, Guatemala City, Secretariat for Central American Economic Integration (SIECA).

CIU (Chamber of Industry of Uruguay) (2020), "Comercio exterior de bienes del Uruguay", Informe Mensual, year 11, No. 124, 12 May [online] http://www.ciu.com.uy/innovaportal/file/90088/1/abril-2020-n124.pdf. 
ECLAC (Economic Commission for Latin America and the Caribbean) (2020a), "Addressing the growing impact of COVID-19 with a view to reactivation with equality: new projections", COVID-19 Special Report, No. 5, Santiago, July.

(2020b), "Recovery measures for the tourism sector in Latin America and the Caribbean present an opportunity to promote sustainability and resilience", COVID-19 Reports, Santiago, July.

(2020c), "Restrictions on the export of medical products hamper efforts to contain coronavirus disease (COVID-19) in Latin America and the Caribbean", COVID-19 Reports, Santiago, May.

IATA (International Air Transport Association) (2020a), "Economic performance of the airline industry", June [online] https://www.iata.org/en/iata-repository/publications/economic-reports/airline-industryeconomic-performance-june-2020-report/.

(2020b), "Airlines Financial Monitor", June [online] https://www.iata.org/en/iata-repository/publications/ economic-reports/airlines-financial-monitor--may-20202/.

INDEC (National Institute of Statistics and Censuses) (2020), "Intercambio comercial argentino: cifras estimadas de mayo de 2020", Informes Técnicos, vol. 4, No. 114 [online] https://www.indec.gob.ar/ uploads/informesdeprensa/ica_06_204EC2AC1D23.pdf.

INEGI (National Institute of Statistics and Geography) (2020), "Información oportuna sobre la balanza comercial de mercancías de México durante mayo de 2020", Comunicado de Prensa, No. 286/20, 26 June [online] https://www.inegi.org.mx/contenidos/saladeprensa/boletines/2020/balcom_o/balcom_ 02020_06.pdf.

IRU (International Road Transport Union) (2020), COVID-19 Impacts on the Road Transport Industry. Executive Summary, June.

Ministry of the Economy of Brazil (2020), "Balança comercial brasileira: acumulado do ano" [online] http:// www.mdic.gov.br/index.php/comercio-exterior/estatisticas-de-comercio-exterior/balanca-comercialbrasileira-acumulado-do-ano.

SIECA (Secretariat for Central American Economic Integration) (2020), "Lineamientos de bioseguridad sector transporte CA" [online] https://www.sieca.int/index.php/lineamientos-bioseguridad-sectortransporte-terrestre-ca/.

UNWTO (World Tourism Organization) (2020), "New data shows impact of COVID-19 on tourism as UNWTO calls for responsible restart of the sector", 22 June [online] https://www.unwto.org/news/newdata-shows-impact-of-covid-19-on-tourism.

World Bank (2020), Global Economic Prospects: June 2020, Washington, D.C.

WTO (World Trade Organization) (2020a), "Trade falls steeply in first half of 2020", Press Release, No. 858, 22 June [online] https://www.wto.org/english/news_e/pres20_e/pr858_e.htm.

(2020b), "E-commerce, trade and the COVID-19 pandemic: information note", 4 May [online] https:// www.wto.org/english/tratop_e/covid19_e/ecommerce_report_e.pdf.

This Special Report is the sixth in a series by the Economic Commission for Latin America and the Caribbean (ECLAC) on the evolution and impacts of the COVID-19 pandemic in Latin America and the Caribbean. The economic and social analysis it offers will be updated as the relevant information becomes available. The preparation of the Report was headed by the Executive Secretary of ECLAC, Alicia Bárcena, with the technical support of the Office of the Deputy Executive Secretary, Mario Cimoli, and the Division of International Trade and Integration of ECLAC.

Copyright (C) United Nations, 2020

E I I C Comisión Económica para América Latina y el Caribe (CEPAL)

www.eclac.org 